Portland State University

PDXScholar

Dissertations and Theses

Dissertations and Theses

Summer 7-26-2018

\title{
Bertolt Brecht's Leben des Galilei: a Mythic Dimension in Epic Theatre
}

Yashowanto Narayan Ghosh

Portland State University

Follow this and additional works at: https://pdxscholar.library.pdx.edu/open_access_etds

Part of the German Language and Literature Commons Let us know how access to this document benefits you.

\section{Recommended Citation}

Ghosh, Yashowanto Narayan, "Bertolt Brecht's Leben des Galilei: a Mythic Dimension in Epic Theatre" (2018). Dissertations and Theses. Paper 4557.

https://doi.org/10.15760/etd.6442

This Thesis is brought to you for free and open access. It has been accepted for inclusion in Dissertations and Theses by an authorized administrator of PDXScholar. Please contact us if we can make this document more accessible: pdxscholar@pdx.edu. 
Bertolt Brecht's Leben des Galilei: A Mythic Dimension in Epic Theatre

by

Yashowanto Narayan Ghosh

A thesis submitted in partial fulfilment of the

requirements for the degree of

\author{
Master of Arts \\ in \\ German
}

Thesis Committee:

Steven N. Fuller, Chair

Carrie Collenberg-Gonzalez

Kathleen Godfrey

Portland State University

2018 


\begin{abstract}
The history of Bertolt Brecht's play Leben des Galilei extends through the writing of its three versions during 1938 to 1955 - a period of two decades that also encompassed the entirety of the Second World War. The period also covers the atom bomb from its development to America's use of the bomb in Hiroshima and Nagasaki, as well as the beginning of the Cold War, which included the sustained threat that nuclear weapons might be used any day. This thesis traces, and offers interpretations of, changes in Brecht's Leben des Galilei from its inception in 1938-1939—when the protagonist, a scientist, is portrayed in a positive light — through the play's American version in 1947, where it bitterly accuses science and scientists of having betrayed society and humanity, and finally to its last version in 1955 , where the protagonist struggles to prevent the normalization — the familiarization — of the threat of nuclear warfare.

Next to the writing of the Leben des Galilei, the thesis also focuses on the main critical readings of the play. A large fraction of the critical readings, but not all of them, interpret the play either as a judgment of science or as an invitation to pass judgment on science.
\end{abstract}

The thesis compares Leben des Galilei with three different groups of other texts. The first comparison is with two other plays that also address the problem of science in the age of nuclear weapons, and the second comparison is with other work of Brecht himself. The first comparison leads to the observation that the muted note of optimism in the final version of Leben des Galilei is exceptional, and the second comparison to the apparently unrelated observation that it was uncharacteristic of Brecht to make explicit a 
certain literary allusion in Leben des Galilei. The two observations converge to a possible common explanation from a comparison with a still third group of texts, a cycle of Native American myths which appear in the oral traditions of various Native American tribes spread throughout the New World.

Finally, the thesis addresses the question of why a modern-day literary text, addressing the essentially modern problem of nuclear warfare, and addressing that problem using the essentially modern techniques of Brechtian theatre, might have structures parallel to the structures of primitive mythology. 
Table of Contents

Abstract $\quad$ i

Table of Contents

List of Tables $\quad$ iv

Introduction: Bertolt Brecht's Leben des Galilei $\quad 1$

Chapter One: The Writing of Leben des Galilei 6

Chapter Two: The Readings of Leben des Galilei 25

Science and Scientists according to Leben des Galilei 25

Extra-Scientific Themes in Leben des Galilei 36

Chapter Three: The Intertextuality of Leben des Galilei 47

Brecht, Friedrich Dürrenmatt, Max Frisch 47

The Classical Mise en abyme $\quad 56$

$\begin{array}{ll}\text { The Mythic Connection } & 65\end{array}$

Chapter Four: Why Mythic Structure in Leben des Galilei 73

$\begin{array}{lr}\text { Works Cited } & 80\end{array}$

Appendix: Horace's Satire 1.8 89 


\section{List of Tables}

Table 1: Epic Theatre, As Distinct from

Dramatic Theatre, According to Brecht

Table 2: The Music of Epic Theatre,

As Distinct from the Music of Dramatic Theatre

76 


\section{INTRODUCTION: BERTOLT BRECHT'S LEBEN DES GALILEI}

Bertolt Brecht (1898-1956) was one of the greatest playwrights of the twentieth century, achieving international significance both for his plays and for the progress the stage owes to him as a theoretician of theatre. Leben des Galilei, on which Brecht worked from 1938 to his death in 1956, is widely considered his masterpiece. It leads the list of Brecht's "five great plays" (Unwin 185); it is, along with Mutter Courage und ihre Kinder (1941; Brecht, Die Stücke von Bertolt Brecht in einem Band, 541-578), one of two plays by Brecht included in a standard canon of German-language theatre (von Wiese 401); it has been called "Brecht's probably most significant and most difficult dramatic work" (Knust 186). In the 75 years since its first version premiered in 1943, Leben des Galilei has attracted a large, amorphous mass of critical opinion. This thesis is an attempt to read three things: the play itself, a sampling of the critical literature about the play, and certain essentials of the theoretical machinery underlying the play. Here, first, is a brief summary of the play:

In the beginning, Galileo is a professor living in Venice, and his immediate difficulties, pecuniary in nature, are the play's first crisis. He is a famous physicist, but his request for a raise is rejected with the explanation that the discoveries that brought him academic fame are not financial successes. As a result, he must accept wealthy students who pay him for private lessons. One of his private students has recently returned from Holland, from where he has brought back a new invention: a telescope. Galileo sees the telescope, copies the design, and presents it to the city fathers of Venice as his own new invention which should be a financial success - which should even have important naval applications. Then he receives his raise. 
The second of three crises in Leben des Galilei begins when a shipment of Dutch telescopes arrive in Venice, thus exposing Galileo in his deception that he had himself invented the telescope. In the meantime, however, Galileo has been using the telescope for astronomical observations, and he has had success of at least two kinds: He has discovered a new star, and he has discovered evidence against Ptolemy's geocentric model of the universe - evidence that supports the heliocentric model of Copernicus. An earlier physicist, Giordano Bruno, was burnt at the stake by the Holy Inquisition for having taught the Copernican model. Galileo uses the new star he has discovered to solve his immediate Venetian crisis: He writes to the House of Medici in Florence, saying that he is naming the new star after the Grand Duke—who is only a boy—and requesting employment as court mathematician. His friend warns him that, if he goes to Florence, then his life might not be as safe from the Inquisition as it was if he stayed in Venice. Galileo ignores the warning and goes to Florence, where he must indeed agree to a compromise with the Inquisition: He must stop working on astronomy. He agrees, and he continues research within the limits of the agreement, studying topics that are not considered controversial by the religious authorities, such as the properties of floating bodies.

The third and final crisis arises when the Pope dies and a Cardinal who had himself studied science becomes the new Pope. Galileo, imagining that the new Pope would be a patron of science, starts working on astronomy again. The Cardinal Inquisitor first convinces the House of Medici to extradite Galileo to Rome, and then convinces the new Pope to allow the Inquisition to threaten Galileo with torture. Galileo recants his teachings and spends the rest of his life under house arrest, a prisoner of the Inquisition. 
But the play has a coda. A former student on his way to Holland pays Galileo a visit on his way out of Italy. Galileo reveals that he has continued his research in captivity, and that he has been maintaining a secret copy of his resulting book, the Discorsi. The former student smuggles the secret copy of Galileo's Discorsi beyond the borders of Italy.

That is an umbrella summary of the play itself, covering all three versions, in which art mimics a rapidly evolving reality. Brecht worked on Leben des Galilei, on and off, from 1938 to his death in 1956, working under different circumstances, in different countries — one can even say in different worlds—and in different languages, writing the play three times over in the process. For the second version, written in English, his collaborator was the great British-American actor Charles Laughton (1899-1962), a master of the art of theatre in his own right. The first chapter of this thesis recounts, in brief, the story of the writing of the three versions of the play, including an account of the changes in the play from one version to the next.

One reason why the play changes over the versions is that it was begun on the eve of the Second World War, but Brecht continued reworking it for the rest of his life. Thus the play changed in response to the dropping of the atom bombs on Hiroshima and Nagasaki, and again in response to the sustained threat, even after the Second World War was over, of the use of nuclear weapons in the Cold War. Many of the critical readings of Leben des Galilei focus upon its interpretation as a statement about science, scientists, and scientific ethics - a statement informed by the lethal developments in modern physics. However, like all great works of art, Brecht's play is open enough to afford a plethora of other readings as well. The second chapter of this thesis is an account of 
various critical readings of the play, with a thorough account of the literature that interprets the play as a statement on science, and a selection of miscellaneous extrascientific readings of the play.

The third chapter is an original analysis of Leben des Galilei in three parts. The first part of the analysis compares the play with two other plays, Die Physiker (1961) by Friedrich Dürrenmatt (1921-1990) and Biedermann und die Brandstifter (1958) by Max Frisch (1911-1991). The analysis determines difference along the optimism-pessimism axis to be one essential way in which Leben des Galilei differs from the plays by Dürrenmatt and Frisch, then goes on to speculate about the possible reasons for the difference.

The second part of the analysis again compares Leben des Galilei with other plays, but uses Brecht's own other work for the contrast; in other words, the second part of the analysis determines one way in which Brecht varied from his own lifelong usual practice when he wrote Leben des Galilei. Specifically, in Leben des Galilei, Brecht alludes to a literary source-Horace's Satire 1.8 — explicitly, which is uncharacteristic of Brecht.

The ultimate observations of the first and the second parts of the comparative analysis appear unrelated. The third and final part of the analysis, then, connects the two observations by suggesting a common explanation for them. The common explanation is based on a new connection between Leben des Galilei and a cycle of animal myths from various Native American tribes throughout North America and South America.

It is, of course, not being suggested that Brecht consciously wrote Native American mythology into his play. In fact, there is no evidence to suggest that Brecht 
ever even heard of the specific cycle of myths in question. And it is not being suggested either that all texts somehow have the same underlying structure-such a hypothesis would almost certainly be a naïve oversimplification. The question arises, then, about the reason why Leben des Galilei has the same structure as the cycle of Native American myths. The fourth and concluding chapter of this thesis attempts to explain the latent mythic structure in Leben des Galilei. Specifically, the chapter argues that the reason mythic structures appear in the Brecht play may be that mythic thought is universal. In other words, that, due to its long history of revision, Leben des Galilei became refined to a point where it had to arrive at universal truths. The play acquired the structure of myths because myths too, being continuously retold, contain universal truths. Read in the reverse, the same argument can count as a simultaneous argument, based on the convergence of Leben des Galilei and the cycle of myths, for the authenticity and the universality of both the play and the mythology. If two people working independently on the same problem arrive at the same answer, it is evidence that their common answer is correct; similarly, the shared structure of Leben des Galilei and the Native American myths is evidence that both texts have a universal truth at their hearts.

[A note about terminology: Throughout this thesis, Galileo-with italicsdenotes Brecht's play, whereas Galileo-without italics-denotes the protagonist of the play. No part of this thesis alludes to the historic Renaissance scientist on whom the protagonist is based.] 


\section{CHAPTER ONE: THE WRITING OF LEBEN DES GALILEI}

Bertolt Brecht's Leben des Galilei went through three full iterations of writing and production between 1939 and 1955. The original version, with 15 scenes, was titled Galileo Galilei, written in 1938-39 in Denmark, and premiered on September 9, 1943, at the Schauspielhaus in Zürich; the second version, completed in 1945-46, opened in the summer of 1947 in Beverly Hills. Brecht finished the third version in Berlin in 1955, with its premiere at the Städtische Bühnen in Köln on April 16 the same year (Frenzel and Frenzel 623). The playwright would continue to return to Galilei throughout the last two turbulent decades of his life.

Indeed, the turbulence of those two decades may have been a reason why Brecht substantially rewrote the play each time it was produced. As one commentator perceptively puts it, "Like Goethe, who worked on Faust throughout his life, Brecht kept returning to the play and revising it in the light of - or, more appropriately - darkness of what was happening to Europe and the world at large" (Harman 116). A text might, presumably, change in response to changes in its context, especially if the changes in its context are violent in nature. And, at a more immediate and personal level, the violence of history drove the playwright literally right around his troubled world as he worked. The completions of the three versions_-in 1939, 1947, and 1955 respectively—fell in three different periods of history and of Brecht's personal life: "Brecht himself was at first living as an exile, close to Germany, on the eve of an impending war; he rewrote the play once in the aura of Hollywood, when an allied victory was at last certain, then again after his own successful reestablishment in his country, within a bitterly divided world" (Brecht, Collected Plays, 265-266; see also Esslin 54 et seq.). And it is, of course, 
probable that these late-life Wanderjahre, forced upon Brecht by world history, influenced the twenty-year evolution of Leben des Galilei.

Similar to Brecht's being hounded out of Germany, then across Russia to America, and finally back to East Berlin with a stop in Zürich, the 1930s and the 1940s also saw tumultuous change on the simultaneous and lethally related level of physics. The story of the atom bomb, from its birth in 1938, to its coming of age in the Pacific Ocean theater of World War II in 1945, on to the testing of the hydrogen bomb in Enewetak Atoll in 1952, paralleled the writing of the three versions of Leben es Galilei: "During Brecht's work on the first version, it became known that Niels Bohr had split the uranium atom; while he and [Charles] Laughton [1899-1962] were preparing the second, the first atom bomb dropped on Hiroshima" (Brecht, Collected Plays, 265), and it is more than likely that the bomb directly impacted the play. At least one commentator considers it a certainty: "Es ist kein Zweifel möglich, daß Brecht sein Urteil über Galilei und die geschichtliche Bedeutung seiner wissenschaftlichen Entdeckungen unter dem Eindruck der Atombombe änderte" (Rohrmoser, "Brecht · Das Leben des Galilei," 404; see also Rohrmoser, "Brecht's Galileo," 118). The developments in nuclear physics constituted an integral part of the context of Leben des Galilei. In fact, this part of the context is what Brecht seems to have chosen to foreground in his text.

Beyond the circumstances—-both his own and his world's—Brecht must also have been influenced by certain factors that affect every play, even plays with less dramatic contexts than Leben des Galilei, factors such as the company of actors at hand for production when he wrote each of the three versions in 1939, 1947, and 1955: "[Galileo] was first written with no clear prospect of production, then rewritten for a specific actor, 
Laughton, and a specific production before an American audience, then rewritten once more for Brecht's own Berliner Ensemble to play in East Berlin" (Brecht, Collected Plays, 265). Playwrights have always been sensitive to the actors in their company, but Brecht was known for taking the matter of the text's sensitivity to actors to an extreme, where decisions about his plays were not simply his own decisions, but rather had to be consensus decisions, decisions of which his whole company had to take ownership. For example, Ernest Borneman (1915-1995), in the course of a combined review of two books on Brecht (Martin Esslin's Brecht: A Choice of Evils and John Willett's The Theatre of Bertolt Brecht), recounts his own experience of acting for Brecht: "Here I can speak from personal knowledge, for it was that year, as a child actor in Der Jasager, that I met Brecht for the first time. He asked us if we agreed with the boy's self-sacrifice and we said no. So he rewrote the play with a different ending and called it Der Neinsager" (Borneman 480). For a playwright with such a writing process, it is only to be expected that the text would change when he first wrote in 1939 with no specific bodies to wear the play's various roles, then rewrote it in 1947 for one of the biggest stars among the actors of his generation, and finally rewrote it again in 1955 for his own company in postwar East Berlin. The second version belongs as much to Laughton as to the atom bomb, and the final version owes at least as much to the Berliner Ensemble as to the hydrogen bomb.

The most obvious surface change from one version to the next was, of course, that of languages - German in 1939, English in 1947, and German again in 1955-“[Galileo] was written in German, then entirely rewritten in English (with Brecht himself contributing in a mixture of English and German), then rewritten in German again largely 
on the basis of the English-language version" (Brecht, Collected Plays, 265). Not that Brecht would compromise his text on account of difficulties expressing himself-that would be quite out of question for a master playwright of Brecht's stature and ego. But it is possible that Brecht, living in America, might have been working directly in English when he rewrote Leben des Galilei for Laughton, and that he, as a result of the new language of his work, visualized his play differently, discovering different points and different points of view. When he worked in German again on the third version, his line of thought must have changed again, but the intermediate period of working in English cannot have failed to have left an aftereffect—he saw everything in German again, but could not unsee what he had seen in English before. The hypothesis here is that human mind can express itself differently when thinking in a different language. This idea goes at least as far back as Wilhelm von Humboldt in the early $19^{\text {th }}$ century: "[Der Sprachen] Verschiedenheit ist nicht eine von Schällen und Zeichen, sondern eine Verschiedenheit der Weltansichten selbst" (27); a more recent, experimental investigation of this phenomenon found that even bilingual subjects think and remember differently when working in different languages (Boroditsky et al 138-140), which suggests that using a different language might affect not only the language user's relatively permanent Weltansichten, but also, minute by minute, the language user's train of thought. In other words, the same person can, conceivably, have different personalities, working differently when working in different languages - when conducting his or her internal monologue in different languages. In this way, the switching of the text's language back and forth between German and English, too, must have contributed to the changes among the three versions of Leben des Galilei. 
The above possible factors that took Leben des Galilei through its multiple rewritings are all briefly discussed in Brecht's Collected Plays (265-266, see also Willett, The Theatre of Bertolt Brecht, 68 et seq.). Because the possible factors are so numerous, there would be little point in trying to attribute specific changes among the play's three versions to specific possible factors. But another factor may, as well, have been responsible for Brecht's changes in the text: the different amounts of time that he spent working on each of the three different versions. Brecht completed the first version in a matter of weeks_-begun in November 1938, drafted in a mere 16 days, revised a few weeks after, and finished by February 1939 (Brecht, Collected Plays, 266-267; Schumacher, Drama und Geschichte: Bertolt Brechts >Leben des Galilei< und andere Stücke, 18-20). When it came to the 1947 version, in contrast, Brecht and Charles Laughton had started it by December 1944, and worked for almost a year up to December 1945 (Brecht, Collected Plays, 268; Schumacher, Drama und Geschichte: Bertolt Brechts >Leben des Galilei< und andere Stücke, 142-143). As for the third version of 1955:

[W]hen Ernst Busch, horrified at the length of the Galileo rehearsals, objected that at this rate it would take four years to put it all together, Brecht slyly replied that four years would not be so bad at that, and in general, observers have always remarked that the benefit of state sponsorship for the Brecht theatre was very precisely this lack of any time pressure, this ideal of thoroughness in which no problem is too small for discussion, no gesture too insignificant for explication and criticism/self-criticism. (Jameson, Brecht and Method, 142).

Thus the three versions took progressively longer to complete. This may seem paradoxical, because in 1939 Brecht was writing with no stage production in sight. One 
reason why Brecht may have needed longer to complete the later versions is the "ideal of thoroughness" (ibid.) that gains in relevance precisely when a play is produced.

More specifically, when working with successive versions of the same play, Brecht may have needed longer because he may have been trying to solve stubborn, enduring problems that he identified, yet could not completely solve in earlier versions of the text. And, in Brecht's own view, both of the first two versions did have such problems: He wrote that the first version of Leben des Galilei was "a great step backwards, far too opportunist ... The play would need to be completely rewritten to convey that 'breeze that comes from new shores,' that rosy dawn of science. It would all have to be more direct, without the interiors, the atmospherics, the empathy" (Brecht, Collected Plays, 267; see also Kruger 37 and Schumacher, Drama und Geschichte: Bertolt Brechts \Leben des Galilei< und andere Stücke, 19). Brecht felt the second version was "still ... formally conventional" (Brecht, Collected Plays, 269), specifically, that "with its interiors and atmospheric effects the construction of the scenes, derived from the epic theatre, makes a singularly theatrical impact" (Brecht, Collected Plays, 269; Schumacher, Drama und Geschichte: Bertolt Brechts `Leben des Galilei< und andere Stücke, 144). For the 1947 production, Brecht "tried in vain to get [his childhood friend and regular scene designer Caspar] Neher [1897-1962] over from Europe" (Willett, Brecht in Context, 141), and the failure of the attempt to bring Neher to America may have been a reason why Brecht was unhappy with the scenes (see Browning 114, Davison 108, and Zipser 100 for the way a modern production of Leben des Galilei approached the problem; see also Stegmann 133 and Spencer 53 for accounts of other modern productions' approaches). Brecht was, already since Die Dreigroschenoper 
(1928; Brecht, Die Stücke von Bertolt Brecht in einem Band, 165-202), wary of theatricalness, of "entheater[ing] (eintheatern) everything" (Vaßen, "Die Alterität des Zuschauers. Das Theater braucht Widerstand - Bertolt Brechts Kritik am 'Eintheatern,"” 74-75). Thus Leben des Galilei undoubtedly changed simply because each version was based on more deliberation on the playwright's part than the earlier version(s). And Brecht may have, as his career matured, spent more and more time on the play because he wanted to solve every last remaining problem with the play.

And, as a final possible factor that may have affected the play's evolution, it seems certain that Brecht had big plans for Leben des Galilei from the very beginning. Already in January 1939, when he was still working the first version — with no stage production in sight—he said in a newspaper interview that the play was "really written for New York" (Brecht, Collected Plays, 267; Schumacher, Drama und Geschichte: Bertolt Brechts >Leben des Galilei und andere Stücke, 19). A reference to his desire to produce the play on Broadway suggests that, since at least 1939, Brecht, increasingly mindful of his legacy, of his own place in history, selected Leben des Galilei-whether consciously or unconsciously—-for his magnum opus. And, in time, Brecht's selection of Leben des Galilei as his magnum opus might have become a reason why he embarked on a personal, two-decade quest for perfection. This particular play may have been chosen to be Brecht's last statement to — and about—the world. His choice may explain the great amount of care the playwright took with the text; his choice may also explain why the play had to keep changing as the playwright and the world changed: At each new stage, the play needed to change because it needed to become the final statement of a new, changed man to—and about—a new, changed world. 
Thus a wide variety of factors all contributed to changing the text of Leben des Galilei over the course of twenty years, and the three versions are records of that changing text at three points in history. An account of the writing of Leben des Galilei should engage with all versions of it, and with all of the changes from one version to the next. A variorum edition of Brecht, which would provide a record of all surviving versions—including manuscript versions—-has been discussed since at least 1968 (Zuther 422), but, unfortunately, it has yet to materialize. The closest thing to a variorum edition so far is a tabular, scene-by-scene summary of the third version which includes, next to its summary of each scene, brief statements of the various ways in which the text differs in that scene from the two earlier versions (in Danter). This tabular summary is written in reverse chronological order, i.e. from a reader's point of view: It is an attempt to represent the journey of a reader who first encounters the final (1955) version, then excavates the text to see what it used to be in the 1947 version, and finally digs even deeper for the text's original form in the 1939 version.

For the purposes of this chapter-an historical account of the writing of Leben des Galile - the relevant point of view is, however, the opposite: This chapter looks at the text from the point of view of the playwright, from which one can see how Brecht himself discovered the text, progressing from the earlier versions to the final one. In other words, this chapter calls for a chronological summary of the different versions, and the remainder of this chapter traces such a summary, not with immediate commentary, but rather to serve as the object of analysis and commentary in the subsequent chapters.

For the purposes of this thesis, the following will serve as primary texts: an early sketch - in the form of a list, from November 1938 - which we shall call version zero, 
that appears in Brecht's Collected Plays (p. 266); the 1939 version, as discussed in outline in Brecht's Collected Plays (pp. 270-296); the 1947 version, Galileo, first published 1952, as printed in the appendix to Brecht's Collected Plays (pp. 403-467); and the 1955 version, Leben des Galilei, first published 1957, as printed in Brecht's Die Stücke von Bertolt Brecht in einem Band (pp. 491-539). The record of the text's evolution will contribute toward the text's interpretations in the later chapters. The section headings below, including the numbering, the capitalization, the abbreviation, and the punctuation, are, verbatim, the entries of the list that constitutes version zero of 1938 , and each section briefly describes, in chronological order, the main ways in which Brecht transformed its material as he wrote the first (1939), second (1947), and third (1955) versions of the play.

\section{PADUA/Welcoming the new age/Copernicus's hypothesis/authoritarian economy in Italy.}

In the 1939 version, the first scene has Galileo speaking about the "new age" and explaining the heliocentric model of Copernicus to his pupil Andrea, who is also his housekeeper's son. Galileo receives Priuli, the procurator of the university. Doppone, a prospective student from an aristocratic family, shows Galileo a telescope newly brought from Holland.

In the 1947 version, the scene is shorter. Galileo's speech is shorter, and he does not explain the heliocentric model to Andrea. The first visitor, Ludovico Marsili, from an aristocratic family, who seeks to be a student, introduces the telescope. Afterward, Priuli visits Galileo. 
In the 1955 version, the order of appearance of the characters is the same as in the second version, as are as their identities. In particular, the second version's condensation of the characters of Doppone and Ludovico into Ludovico is retained, and Ludovico remains an aristocrat, like Doppone and unlike the first version's Ludovico. On the other hand, the scene is much more thoroughly developed than in the second version: Galileo's explanation of the Copernican model to Andrea is restored; Galileo's speech is expanded with even more detail than in the first version.

\section{SIGNORIA/Landscape.}

In the 1939 version, Galileo, accompanied by Andrea, who carries the telescope, and Priuli, presents the telescope to the city fathers of Venice. Priuli speaks about its possible military applications and adds that Galileo hopes to continue serving Venice. At the end of the scene, Doppone barges in and berates Galileo, saying that the telescope's cover should have been green.

In the 1947 version, Virginia appears in this scene, carrying the telescope; Ludovico is present from the beginning. Priuli introduces Matti, an iron founder from Florence. The scene ends the same way as in the first version, with Ludovico speaking what used to be Doppone's line - that Galileo merely changed the colour of the telescope's cover from green to red.

The 1955 version does away with the character of Matti-indeed, it does not introduce the idea of Florence in this scene at all. Instead, the character of Federzoni, lens-grinder and assistant to Galileo, appears. And, once again, the scene is fleshed out in far richer detail than in the second version. 


\section{RESEARCH/Danger of the truth/speech about reason and its seductions.}

In all three versions, Galileo discovers, in this scene, proof for the Copernican model. Galileo's friend Sagredo warns him that such research could bring persecution. Priuli arrives to say it has been found out that the telescope had already been discovered in Holland. Galileo, disregarding Sagredo's advice, writes to Florence.

For this scene, the difference between the three versions is the extent to which the dialogue is developed. The 1947 version is, yet again, the shortest by far, and the 1955 version is the most well-developed of the three.

\section{DEMONSTRATIONS/The addicts of authority exhorted to see.}

In the 1939 version, the fourth scene starts with Andrea and Cosmo fighting, and continues with court scholars looking through the telescope. At the scene's end, the plague is in Florence, and a carriage is on its way to take Galileo's household away.

In the 1947 version, this scene too becomes much shorter, and the fight between Andrea and Cosmo does not happen. Galileo invites the court scholars to look through the telescope themselves, but there is no mention of the plague.

In the 1955 version, the fight between Andrea and Cosmo is restored, but the plague is not. And, as with the previous scenes, here too Brecht develops the whole scene in greater detail than in either of the first two versions.

In the 1947 version, Brecht and Laughton introduced almost every scene with brief song, the only exceptions being this scene and the later scene between Pope Urban VIII and the Cardinal Inquisitor. In the 1955 version, Brecht translated into German all of the preludes already present in 1947, but only this scene, scene four, got two brand- 
new lines of lyric prelude. The following scene — scene five, plague-which was cut for 1947, has no prelude in the 1955 version; the scene between The Pope and the Cardinal remains without a prelude in the 1955 version.

\section{PLAgUE.}

In the 1939 version, Brecht already introduces the plague at the end of the previous scene. This scene shows Galileo staying back, in spite of the plague, in order to continue his research.

In the 1947 version, the plague is completely cut. The fifth scene of the second version is the evaluation of the Copernican system at the Collegium Romanorum.

In the 1955 version, Brecht divides scene 5 into two sub-scenes. 5a shows the arrival of the plague in Florence, with a carriage coming to take Galileo's household away from the city, but Galileo stays behind, with Frau Sarti staying back to look after him; $5 b$ has the same content as the fifth scene of the first version.

\section{COLLEGIUM ROMANUM/The Copernican system ridiculed.}

In the 1939 version, the sixth scene has the Collegium Romanorum confirming that Galileo's discoveries are correct. The scene ends with an astronomer pointing out Galileo to the Cardinal Inquisitor, who considers Galileo's telescope to be a very interesting instrument.

In the 1947 version, this scene too- which is the fifth scene, because the plague was cut - becomes much shorter. Much of the preliminary dialogue is left out, and the scene ends with the short monk telling Galileo, "You have won." 
In the 1955 version, the first version is restored and revised. Galileo answers the short monk, saying that it is not he, but reason that has won. The end of the scene has a switch from the first version: The doorman tells Galileo that the man who just entered the room is the Cardinal Inquisitor.

\section{THE DECREE/On the church's responsibilities/the ch. System too all- embracing.}

In the 1939 version, the seventh scene-the ball scene-features Doppone again, and also introduces Virginia's fiancé Ludovico, who is not an aristocrat but a commoner. Church officials - Cardinal Bellarmine in a fox's costume and Cardinal Barberini as a donkey - confront Galileo, informing him that the church has issued a decree against the Copernican model. The Cardinal Inquisitor appears at the end of the scene.

In the 1947 version, this scene too- the sixth scene- becomes shorter, but not as drastically shorter as many of the preceding scenes. Ludovico, the student from an aristocratic family from the first scene, is newly engaged to Virginia; another change is in the animal symbolism: Cardinal Bellarmine is a lamb and Cardinal Barberini a dove.

The 1955 version is, once again, slightly longer than the first version, one addition being the madrigal of Lorenzo de Medici. The two cardinals' costumes match the ones in the American version: Bellarmine is still a lamb, and Barberini is still a dove.

\section{7a. CONVERSATION/The monk's parents/Horace.}

Already in the 1939 version, this became its own scene, separate from the ball scene. Galileo receives the short monk as a visitor, and they have a conversation about 
science and religion. They also talk about the monk's parents, who are peasants. Galileo alludes to Horace's satire 1.8 (see the appendix for the full text of the satire in Horace's original Latin; a classic English translation, in prose, is included in the second section of chapter three below).

In the 1947 version, Horace's satire is still mentioned, but the allusion is not elaborated upon. The allusion and its detailed development are fully restored in the 1955 version.

\section{The sunspots/On science/Keunos.}

In the 1939 version, scene nine opens with Galileo experimenting with floating bodies. Mucius, who has written a book against the Copernican model, is dismissed by Galileo. Virginia and Frau Sarti talk about horoscopes in anticipation of Virginia's wedding. Andrea asks about sunspots, and an elderly scholar questions the ethics of remaining silent. Galileo responds, parabolically, "about the man who was asked if he would serve his enemy, served him for seven years till he died, and then bundled up his corpse, scrubbed out the room, breathed deeply and replied, 'No"' (Brecht, Collected Plays, 281). Everyone laughs, with the sole exception of Andrea, who does not like the story.

In the 1947 version, scene eight begins with the conversation about horoscopes between Virginia and Frau Sarti. Mucius does not appear, and the parable of the way Keunos refused to serve his enemy is also cut. In the final version, the order of the events in scene nine is as in the American version. In the 1955 version, Brecht restores Galileo's exchange with Mucius, but leaves out the parable about Keunos refusing to 
serve his enemy. The Keunos parable cut from this scene appears today as part of the third entry (9-10) in Geschichten vom Herrn Keuner, another lifelong project of Brecht, on which he worked from 1935 to his death-even longer than he worked on Leben des Galilei.

\section{The new age without fear/strict research/hope in working people.}

Already in the 1939 version, this is not a separate scene, but combined into one scene together with the material of the previous section. Thus, scene nine of the 1939 and 1955 versions, and scene eight of the 1947 version, all continue with Ludovico bringing news that Cardinal Barberini, a scientist, is becoming the new pope. Hearing this, Galileo immediately abandons the study of floating bodies to take up the subject of sunspots, causing Ludovico to break off his engagement to Virginia. Galileo speaks about writing not in Latin, but instead in the vernacular, so that the common people could read what he would write.

\section{9a. BALLAD.}

In all three versions, this is a separate scene in its own right-scene 10 in the 1939 and 1955 versions, scene nine in the 1947 version. Street performers perform a ballad about "Galileo, the Bible killer" (Brecht, Collected Plays, 447) and how his work transforms the world for everyone, and the common people listen. Brecht abandoned the ballad from the 1939 version, writing a fresh ballad — with a completely different structure - for the English-language version, and the 1955 version translated the Englishlanguage ballad to German. 


\section{THE INQUISITION'S SUMMONS.}

In the 1939 version, scene 11 has Galileo and Virginia waiting long at the Medici palace to see Cosmo de Medici and give him Galileo's book. Gaffone, the rector of the university, passes but barely greets Galileo. Galliardo, director of the artillery equipment, passes but he too — uncharacteristically for him—does not greet Galileo. A student who wants to stop and speak with Galileo is led away by his tutor. The Cardinal Inquisitor passes. Then Cosmo de Medici appears, but he snubs Galileo by leaving without accepting the book. The scene closes with a palace official coming up to Galileo and informing him that the Florentine court can no longer shield him from the Inquisition, that he is being extradited to Rome right away.

In the 1947 version, neither Galliardo nor the student appear in scene 10, but Matti, the Florentine iron founder from scene two, appears and expresses the working people's support for Galileo. Galileo tells Virginia that he might travel to Padua, where Sagredo has invited him to visit. Next, the Lord Chamberlain appears, tells Galileo that Cosmo de Medici does not have time to see him. Galileo tells Virginia that they are going to escape from Florence in a coach that is waiting for them at the house of a lensgrinder, but, before they can leave, the Lord Chamberlain re-appears and tells them that they are being extradited to Rome.

In the 1955 version, where scene two did not feature a Florentine named Matti, the exchange with an iron founder is retained, even developed out to be twice as long as in the second version, but features a fresh character named Vanni. Cosmo de Medici does appear and leave without the book. Otherwise, scene 11 is the similar to scene 10 of the second version. 


\section{INQUISITION/Condemnation of doubt.}

In the 1939 version, scene 12 has two parts. The first part has Pope Urban VIII, formerly Cardinal Barberini, and the Cardinal Inquisitor arguing about Galileo's fate. They reach a compromise where Galileo is to be threatened with torture, but not tortured, and they are sure that the threats would be sufficient to make Galileo recant. The second part shows Galileo, detained in a room by two officials, waiting with the hope of an audience with the pope before the inquisition begins.

Scene 11 of the 1947 version shortens the part with the pope and the Cardinal Inquisitor, and completely does away with the part that showed Galileo in his cell. Scene 12 of the 1955 version develops the first part in better detail, but it does not restore the second part.

\section{RECANTATION/Praise of steadfastness.}

Scene 13 in the 1939 and 1955 versions, and scene 12 in the 1947 version, are identical except for minor line revision and re-arrangement of dialogue. Galileo’s disciples await the result of the inquisition; Galileo recants, and Andrea accuses him of having betrayed science.

\section{THE PRISONER/Passage from the Discorsi/On the scientist's duty/On expropriation/The new age, a harridan.}

In the 1939 version, scene 14 shows that Galileo, who is in house arrest, has set up a system to smuggle out his writings with a stove fitter. The Inquisition is aware that his writings are reaching foreign countries, and has, recently, even intercepted a letter to 
Strasbourg promising a new manuscript. The stove fitter brings back a manuscript, saying that one of his men has been arrested. A doctor visits Galileo. Andrea, on his way to Holland, visits Galileo, whom he still accuses of intellectual betrayal. Galileo gives Andrea the Discorsi to smuggle out of Italy, and Andrea leaves with the manuscript.

Scene 13 of the 1947 version has neither the stove fitter nor the doctor, Galileo is not already smuggling his papers to foreign countries, and the Inquisition does not suspect anything. Andrea receives the Discorsi to smuggle out to Holland, and experiences a moment of revelation where he sees Galileo's recantation as an act of heroism in the service of science. Galileo, however, does not consider his own actions heroic.

Scene 14 of the 1955 version is similar to scene 13 of the second version, but, again, developed in better detail. When Andrea visits, the dialogue is more about social betrayal than about intellectual betrayal; Galileo speaks of a version of the Hippocratic Oath for scientists - this is one part of the play that changed in response to developments in the field of nuclear warfare.

\section{SMUGGLING.}

Scene 15 of the 1939 and 1955 versions, and scene 14 of the 1947 version, are essentially the same. In all three versions, the "harridan" planned for the penultimate scene in version zero is moved to this scene. Andrea successfully crosses the Italian border with the manuscript of Galileo's Discorsi, making it possible to read the play as a text ending on an optimistic note. 
The above, then, is an outline of the changes in Leben des Galilei, from one version to the next, over three versions. The next order of business is to interpret the play, including the ways it changed from version to version - this is the program of the next chapter. 


\section{CHAPTER TWO: THE READINGS OF LEBEN DES GALILEI}

Brecht's Leben des Galilei has received ample critical attention over the course of its 80 -year history. This chapter summarizes some of the major critical interpretations of the play.

Leben des Galilei offers multiple readings spanning a wide variety of themes, but a substantial part of the critical literature about the play reads it as a dialogue about the atom bomb (as do a number of stage productions - see, for example, Ohlson 164). In view of the critical emphasis on modern physics as a theme in the play, this chapter is organized in two sections. The first of these sections describes various theorists' readings of Leben des Galilei as a statement about nuclear weapons, and the second section presents critical readings that relate it to an assortment of themes other than nuclear weapons. These extra-scientific themes include possible symbolic interpretations of the Church as it appears in Leben des Galilei, the role of sensual pleasures as a force driving the title character, flight from persecution and life in exile, and political statements.

\section{SCIENCE AND SCIENTISTS ACCORDING TO LEBEN DES GALILEI}

The first critic of any piece of literary writing is, of course, its author. On the question of what Leben des Galilei has to say about science and scientists, Brecht himself wrote at least twice — once before 1945, when the first atom bomb was dropped, and once again after the war.

Writing in 1941, Brecht describes Galileo in definitely positive terms: "My Galileo is a powerful physicist with a tummy on him, a face like Socrates, a vociferous, full-blooded man with a sense of humor, the new type of physicist, earthly, a great 
teacher” (Brecht, “The New Type of Physicist;” see also Brecht, "Der neue Physikertyp"). This Galileo is a man in his prime, yet he is not a hero, but rather entirely human; Brecht also explicitly labels him the "new type of physicist," i.e. Brecht intends Galileo as a representation of the pioneers of nuclear physics, contemporaries of Brecht, who were splitting the atom even as Brecht worked on the 1939 version of Leben des Galilei. The sketch continues to cover the scientist's appearance and non-verbal behaviour: "Favorite attitude: stomach thrust forward, both hands on the buttocks, head back, using one meaty hand all the time to gesticulate with, but with precision; comfortable trousers for working in, shirtsleeves or (particularly at the end) a long whitish-yellow robe with broad sleeves, tied with a cord around his stomach" (Brecht, “The New Type of Physicist;" see also Brecht, "Der neue Physikertyp”). If this description is reminiscent of the exaggeratedly stylized characters of commedia dell'arte, the paradox is that Brecht is actually writing with the express purpose of preventing a stylization — a different stylization — of his title character: "It's important that you shouldn't idealize Galileo. You know the kind of thing - the stargazer, the pallid intellectualized idealist. I know you wouldn't if left to yourself, but the pictures you'll see in the books are already idealized" (Brecht, "The New Type of Physicist;" see also Brecht, "Der neue Physikertyp").

Brecht is trying to break the stereotype of the ivory-tower scientist by staging a Galileo full of life's force and in touch with the working class. And he emphasizes that Galileo the character must have a prominent lighter side: “Don't be scared of a little humor. History without humor is a ghastly thing" (Brecht, "The New Type of Physicist;" see also Brecht, "Der neue Physikertyp"). The humour, of course, would also serve to 
make sure that Galileo becomes human, as opposed to a superhuman hero. The one thing that is conspicuous by its absence in Brecht's 1941 conception of Galileo, though, is the ominous note to the effect that mass death and destruction are a possible result of advances in science.

By the time Brecht revisited the question of Galileo's character in 1947—after the war had ended with two atom bombs - the direction of his thought had turned away from a wish to show the "new type of physicist" on his stage in a positive light. Of course Galileo's decision to recant his teachings on astronomy when confronted by the Inquisition still had the positive consequence that Galileo lived to continue his work. This meant the recantation had the paradoxical effect of actually advancing science. Brecht does acknowledge this positive consequence of the recantation. However, he is still sharply critical of Galileo's decision to recant. He emphasizes the social consequences, and finds the consequences disastrous:

The fact is that Galileo enriched astronomy and physics by simultaneously robbing these sciences of a greater part of their social importance. By discrediting the Bible and the church, these sciences stood for a while at the barricades on behalf of all progress. It is true that a forward movement took place in the following centuries, and these sciences were involved in it, but it was a slow movement, not a revolution; the scandal, so to speak, degenerated into a dispute between experts. The church, with all its forces of reaction, was able to bring off an organized retreat and more or less reassert its power. (Brecht, "Praise or Condemnation of Galileo?" 225; see also Brecht, "Preis oder Verdammung des Galilei?" 12) 
Brecht, in 1947, is mindful of the price at which Galileo purchased his life and his opportunity to continue his work: Had Galileo refused to recant, had Galileo been burnt at the stake, the common people could have revolted, because, as previously established in the scene with the ballad, Galileo's work had already spread among the common people - and the revolution could have delivered the common people from the oppression of the Church's authority. And Brecht, in 1947, is contemptuous of what was salvaged by Galileo's decision: Galileo, subsequent to his recantation, only worked in secret, and, because his new writings were only available to scientists in foreign countries, it all "degenerated into a dispute between experts," i.e. science was, once again, confined to precisely the type of "pallid intellectualized idealist" that Brecht earlier —in 1941—had wanted to replace with his Galileo (Brecht, "The New Type of Physicist;" see also Brecht, "Der neue Physikertyp"). Science was once again confined to the ivory towersymbolized by Galileo being confined to house arrest by the Inquisition — and the cruel irony is that Galileo made a conscious, deliberate decision go into confinement and continue to live, when he could have, instead, chosen to die, in which case science would have still been free, could have still been among the common people, and the natural course of that free science could have brought down the Church. In other words, Brecht accuses Galileo of sacrificing the possibility of a revolution in order to preserve his own life, and also of allowing the Church to survive in order to preserve his own life, when he had the choice to die and bring about the demise of the Church. Brecht even goes on to use a religious metaphor to drive home his point, writing, "Galileo's crime can be regarded as the 'original sin' of modern natural sciences" (Brecht, "Praise or Condemnation of Galileo?" 225; see also Brecht, "Preis oder Verdammung des Galilei?" 
12). Galileo's recantation has, by allowing the Church to recover, condemned mankind to eternal exile from a Garden of Eden where common people, peasants, workers could have been free.

Of course, the above must appear dubious if read as a statement about the real-life Catholic Church and the historic Galileo. In the play, however, Brecht magnifies Galileo's importance. This is evidenced by Galileo's own lines from his long speech to Andrea in the penultimate scene: "Ich habe zudem die Überzeugung gewonnen, Sarti, daß ich niemals in wirklicher Gefahr schwebte. Einige Jahre lang war ich ebenso stark wie die Obrigkeit" (Brecht, Die Stücke von Bertolt Brecht in einem Band, 537). In the universe of the play, Galileo is the Church's equal in power.

Beyond accusing Galileo of sacrificing the common good in order to save his own skin, Brecht, in 1947, also holds Galileo directly responsible for the atom bomb: "The atom bomb is, both as a technical and a social phenomenon, the classical end-product of [Galileo's] contribution to science and his failure to contribute to society" (Brecht, "Praise or Condemnation of Galileo?" 225; see also Brecht, "Preis oder Verdammung des Galilei?" 13). Galileo's responsibility, according to Brecht, is direct in the sense that, in deciding to live and let the Church live, abandoning the working people to their fate, instead of exposing the Church in its lie when he had the chance, thereby freeing the people from the power of the Church, Galileo founded a certain tradition of science siding with authority against the interests of the common man. And this is the tradition that, in time, grew to the stage where science is even capable of entering the service of warlike nations to devise such weapons as the atom bomb. And then the nations use the weapons built by science to kill entire cities of common people, which is what happened 
in Hiroshima and Nagasaki — and which, on account of the cold war, still remained a very real threat when Brecht wrote the third, final version of Leben des Galilei.

In addition to his own writings about science and scientists in Leben des Galilei, the record of Brecht's oral discussions with others also sheds light on the subsequent development of the issue in the third version of the play. Just days after the 1955 premiere of Leben des Galilei in Köln, Brecht spoke to Ernst Schumacher in München, and Schumacher reports:

Brecht bestätigte [Ernst Schumacher], dass er unter dem Eindruck der Weiterentwicklung der A- zur H-Bombe, der Atombombenversuche der USA auf dem Eniwetok-Atoll und deren verheerende Auswirkungen auf japanische Fischer, schließlich auch durch den Prozess gegen Robert J. Oppenheimer im Jahr 1953, die Tendenz der amerikanischen Fassung des Galilei noch verstärkt habe. Der zeige ihn als genialen Wissenschaftler, der sein geistiges Produkt den gesellschaftlichen Machthabern überlässt, die "es zu gebrauchen, um es zu missbrauchen.” (Schumacher, "Wie Brecht beinahe ein Einstein-Stück schrieb”) In other words, when the world war ended, nothing improved on the front of science. Indeed, things worsened, from the atom bomb to the hydrogen bomb, from developing a bomb in the desperate situation when, in the middle of the war, there was reason to fear that the other side was developing the bomb too, to testing a bomb in the Pacific Ocean as a matter of course during the cold war. These new developments led Brecht to write into the play's third version yet another thing Galileo could have done, had he not recanted: "In die deutsche Neufassung habe er noch den Satz eingefügt, dass - so sinngemäß Galilei auch zum Anstifter eines `hippokratischen Eides der Naturwissenschaftler` hätte 
werden können, wenn er nicht abgeschworen hätte" (Schumacher, "Wie Brecht beinahe ein Einstein-Stück schrieb")—beyond the opportunity to make himself into the champion of the common, working man, Galileo also had — and refused — the opportunity to portray, once and for all, science into the champion of good against evil—in Brecht's own immediate context, the opportunity to make science into the champion of peace against nuclear warfare.

Later critics have carried forward the discussion beyond a Hippocratic Oath for scientists to activism for peace: "[T]his play is to raise questions about the scientists and their responsibilities. If we go back to Galileo himself, then, it is because of Oppenheimer and the atomic bomb; and the play thereby insensibly becomes an allegory of the anti-nuclear movement" (Jameson, Brecht and Method, 154). It is not sufficient that science should merely not submit to, and serve, the powers of destruction. Science must actively resist those powers, at least to the point where the damage is neutralizedthe damage that has been done directly by science's own previous collusion with those powers.

One way to discuss Galileo's recantation is, of course, to compare and contrast him with someone who does not recant, and Leben des Galilei also features, albeit offstage, such a character: the earlier physicist Giordano Bruno, for whose extradition to Rome, and subsequent burning at the stake, Galileo holds Priuli responsible in the first scene of the 1955 version. Priuli's says the reason why Bruno was extradited was not that he had taught the model of Copernicus, but rather that he was not Venetian. The Nazis had been prone to use the label "Jewish science" for the work of Jewish scientists - and to distinguish it from "German science," the work of scientists the regime 
considered German — and Priuli's answer to Galileo's charge may well have been a fleeting allusion to the Nazi distinction between "German science" and "Jewish science." Of primary interest here, however, are not Priuli's motives, but rather the consequences of Bruno's refusal to recant. The entire debate about the atom bomb and ethics in Leben des Galilei is teleological, is about consequences. If one had the luxury to ignore the consequences, then, of course, the splitting of the uranium atom was the pièce de résistance of modern physics, the crown jewel of the "new type of physicist" whom Brecht had so joyfully toasted in 1941.

And the consequences of Bruno's refusal to recant were, to say the least, anticlimactic to the point of being a cautionary tale: He was burnt at the stake, and nothing else happened. There was no revolution. Had he recanted, he could have lived on and, like Brecht's Galileo, continued his research in secret. Science lost something when Bruno decided to die rather than give in, and society did not gain anything either. In fact, society may have lost something as well, because it is entirely possible that other scientists — such as Galileo — were intimidated by the spectacle of his death into giving up programmes of research that ran the risk of drawing the Church's disapproval. One must ask, then, how much sense it makes to condemn Galileo for recanting.

Brecht touched upon the comparison of Galileo with Bruno when he wroteduring 1938-1939, i.e. precisely when he wrote the first version of Leben des Galilei-a short prose piece about Bruno called Der Mantel des Ketzers (Schumacher, Drama und Geschichte: Bertolt Brechts ২Leben des Galilei< und andere Stücke, 19; text in Brecht, Kalendergeschichten, 16-25). Four decades later, the poet Volker Braun (1939- ) addressed the issue in two poems, one called Bruno and another called Prozeß Galilei. A 
comparative analysis of Leben des Galilei, Der Mantel des Ketzers, and both of Braun's poems identifies the fallacy in defending Galileo's actions by pointing out Bruno's fate: "[Brecht und Braun] [b]eide schreiben sie ja dem Pisaner/Florentiner eine zeitweilige Machtstellung und daraus erwachsende Einfluß- und Wirkungsmöglichkeiten zu, welche, mindestens für die damalige Zeit, kaum beherrschender gedacht werden könnten” (Grimm, "Der Nolaner und der Pisaner: Zwei Italiener bei Bertolt Brecht und Volker Braun," 181). Galileo — the Galileo we see in Leben des Galilei-had become so powerful by the time when he faced the Inquisition that what had happened to Bruno earlier could not possibly have happened to him. The Church could not have burnt a man of his stature at the stake - this is supported by the scene between Pope Urban VIII and the Cardinal Inquisitor: "Schließlich ist der Mann der größte Physiker dieser Zeit, das Licht Italiens, und nicht irgendein Wirrkopf. Er hat Freunde. Da ist Versailles. Da ist der Wiener Hof" (Brecht, Die Stücke von Bertolt Brecht in einem Band, 530). Any injury that the Church caused to Galileo could have sparked social unrest—-this is supported by the conversation between Galileo and the iron-founder Vanni in scene 11 of the 1955 version: "Ich stehe und falle mit Männern wie Sie, Herr Galilei. Wenn man je versuchen sollte, etwas gegen Sie zu Machen, dann erinnern Sie sich bitte, daß Sie Freunde in allen Geschtszweigen haben. Hinter Ihnen stehen die oberitalienischen Städte, Herr" (Brecht, Die Stücke von Bertolt Brecht in einem Band, 528). And Galileo was aware of his own position of power, as he confirms in his farewell speech to Andrea: "Ich habe zudem die Überzeugung gewonnen, Sarti, daß ich niemals in wirklicher Gefahr schwebte. Einige Jahre lang war ich ebenso stark wie die Obrigkeit" (Brecht, Die Stücke von Bertolt Brecht in einem Band, 537). At the time when the Inquisition brought him 
from Florence to Rome, Galileo enjoyed international support; more importantly, he had the support of the common people; and he even knew his own power.

In Brecht's view, the power that Galileo had attained before he recanted stemmed from the people. He had grown powerful because, as evidenced in the ballad scene (scene 10 of the 1955 version), the common people had proved receptive to his work. It must, then, count as yet another depth of betrayal that he stopped short of using his position of power to relieve the people from the authority of the Church in spite of the fact that he had received his power from the people. Furthermore, there is a redoubling of irony in between Bruno's sacrifice of self that served no purpose and Galileo's betrayal of society from a position where resistance from him might have, finally, given society freedom. Any attempt to redeem Galileo by means of a comparison with Bruno is a false parallel.

However, the question of Galileo's ethics is still not quite a one-dimensional issue. Galileo's character has responsibilities in not one, but two directions:

Das Verhältnis von Wissenschaft und Gesellschaft ist für Galilei definiert durch das Problem der “doppelten Verantwortung” des Wissenschaftlers, einmal gegenüber der Wissenschaft, insofern sie nach ihrem Selbstverständnis nur dem Geist der Wahrheit verpflichtet ist und im übrigen sich selbst genügt, zum anderen gegenüber die Gesellschaft, deren Wohlfahrt sie dienen soll. (Zimmermann 95)

In other words, Galileo — in general, any scientist—-has both a responsibility to science and scientific truth and a responsibility to society and social good. The discussion in this section has, for the most part, condemned Galileo for his apparent abandonment of his 
responsibility to society. It can, however, also be argued that, for a human, for a being made of flesh and blood, it is not possible to truly fulfill either of the two responsibilities - that Galileo, being no super-human hero, but only human, was, from the very beginning, doomed to fail on both counts:

Das Versagen Galileis gegenüber dem Anspruch der “doppelten Verantwortung” ist letzlich zurückzuführen auf den Gegegnsatz zwischen der Idee einer an soziale Verantwortung gebundenen Wissenschaft und einer Wirklichkeit, die dadurch gekennzeichnet ist, daß auf der einen Seite die Freiheit von Lehre und Forschung der staatlichen Zensur unterworfen ist und auf der anderen Seite auch ein großer Gelehrter und Forscher aus menschlicher Schwäche unter den Bedingungen eines unmenschlichen Regimes weder der sozialen noch der wissenschaftlichen Verantwortung gerecht zu werden vermag. (Zimmermann 97)

In terms of the three stages of crisis outlined in the introduction to this thesis, Galileo is already doomed when, in the first two scenes, he-already a world-famous scientistmust first haggle with Priuli for his salary, must then pass off the telescope as his own invention in order to get the raise he needs. He is doomed a second time when, in the third scene, he must write his grovelling letter to Florence. And only then-da aller guten Dinge drei sind - he is doomed a third time when, off-stage in scene 12 of the 1955 version, he must recant when the Inquisition shows him the instruments of torture.

Werner Zimmermann's point above — that the play's structures of power and authority left Galileo necessarily incapable of fulfilling either of his twin responsibilities, one to science and the other to society-illustrates Abraham Maslow's hierarchy of needs, a theory that was, incidentally, first published in 1943, i.e. was also developed 
around the time when Brecht wrote Leben des Galilei. According to Maslow, "the basic human needs are organized into a hierarchy of relative prepotency" (“A Theory of Human Motivation,” 375; Motivation and Personality, 17)—human needs form a pyramid, and a human being cannot rise to address the needs situated higher on the pyramid unless his or her needs at the pyramid's lower levels are satisfied first. Esteem, which Galileo appears to lose by recanting, is the second highest level of the pyramid (Maslow, “A Theory of Human Motivation,” 381-382; Motivation an Personality, 2122). Physiological needs, which are what he struggles to meet in the first three scenes, are the pyramid's lowest level (Maslow, “A Theory of Human Motivation,” 372-376; Motivation and Personality, 15-17), and safety, which is what is at stake in the Inquisition, is the second lowest level (Maslow, "A Theory of Human Motivation," 376380; Motivation and Personality, 18-20). According to Maslow's theory, a human being is not capable of being mindful of his or her need of being esteemed when either his or her physiological needs are not satisfied-“"Erst kommt das Fressen, dann kommt die Moral” (Brecht, Die Stücke von Bertolt Brecht in einem Band, 191)—or his or her safety is threatened. In other words, the reason why Galileo must recant is that he is human. And the fact that Galileo is human, not a hero, is precisely Brecht's point in the famous "Unglücklich das Land, das Helden nötig hat" (in scene 13 in the 1955 version). Galileo is human - that is his tragedy, and that alone should be his epitaph.

\section{EXTRA-SCIENTIFIC THEMES IN LEBEN DES GALILEI}

The critical consensus certainly seems to be that the major theme of Leben des Galilei is science and its ethics, as seen in the previous section. However, Brecht's play 
also has several additional themes that contribute to its complexity. This section probes a selection of critical literature on an assortment of extra-scientific themes in Leben des Galilei. Once again, the discussion opens with two pieces of commentary from Brecht himself - one on the Church as it appears in the play, another on the sensual dimension of Galileo's character-and then continues with contributions from other critics.

One of the play's auxiliary themes is, obviously, the Church, which the preceding section has already, and in loud colours, painted as the ultimate, victorious antagonist in Leben des Galilei. It is well-known that Brecht had a negative view of religion. For example, at the end of June 1938 — just months before starting the first version of the play_-"Brecht spricht von seinem eingewurzelten, von der Großmutter her ererbten Haß gegen die Pfaffen" (Benjamin 165). Brecht himself, however, pleaded against staging Leben des Galilei as a play against the Church: "Es ist für die Theater wichtig, zu wissen, daß dieses Stück einen großen Teil seiner Wirkung verlieren muß, wenn seine Aufführung hauptsächlich gegen die katholische Kirche gerichtet ist" (Brecht, "Darstellung der Kirche," 14, italicization Brecht's; see also Brecht, "Portrayal of the Church,” 216). Leben des Galilei is a work of literature, and literature, quite generally, derives its power and its interest, from its insistence upon figurative language. To read any element of a literary text only literally—instead of also figuratively—effectively annihilates the text by limiting its meaning and denies its plurity of meaning. Accordingly, where Brecht writes "Church," he is specifically inviting the reader to read the Church also as a symbol. There is nothing in the play itself that explicitly rules out letting "Church" be the actual Church. However, the reader cannot take that literal reading to be the final reading - just as the character of Galileo is really intended to be 
read as the "new type of physicist," even though there is nothing in the play itself that explicitly rules out letting Galileo be the actual Galileo of history, the Renaissance physicist Galileo. The text, simply because it has been labelled a literary text by its author, demands that the reader must understand it figuratively (Empson x, 234, where the technique is called "ambiguity"; Todorov, The Fantastic: A Structural Approach to a Literary Genre, 62; Todorov, The Poetics of Prose, 240, 250).

The reader must ask, then, what the Church in Leben des Galilei should be a symbol of, and Brecht suggests: "In dem vorliegenden Stück fungiert die Kirche, auch wo sie der freien Forschung entgegentritt, einfach als Obrigkeit" (Brecht, "Darstellung der Kirche," 14; see also Brecht, "Portrayal of the Church," 216). The antagonist of Leben des Galilei is not solely religion, but rather authority. Brecht gives his abstract antagonist the concrete form of a three-headed monster, so to speak, corresponding to the three stages of crisis outlined in the introduction to this thesis. The first head is the Republic of Venice and the second head is the House of Medici; the Church in Leben des Galilei is not literally the Church, but rather the third, final head of the monster of authority. Brecht goes on to add: "Die weltlichen Interesse hoher Würdenträger satirisch aufs Korn zu nehmen, scheint mir billig" (Brecht, "Darstellung der Kirche," 14; see also Brecht, "Portrayal of the Church," 217). No matter how much "Haß gegen die Pfaffen" (Benjamin 165) Brecht may have inherited from his grandmother, he is too great an artist to take cheap shots at anyone or anything from the stage of his art.

The role of the Church in the play mirrors in an interesting way in Galileo's decision to change the language of his writings: "Galilei, like Luther, decides to appeal to the broadest possible base by writing in the vernacular" (Simpson 174). Even though 
the Church in Leben des Galilei is not only the Church, but can also be read as a symbol of authority, the progress of the play parallels to a certain point in the plot the history of the Church. Galileo, like Martin Luther before him, starts writing in the vernacular after scene nine of the final version, and, in the following scene, his work, like Luther's translation of the Bible, reaches the common people. In this way, Galileo has another possible symbolic reading—-beyond representing the "new type of physicist," he can also stand for the democratization of knowledge. In the universe of Leben des Galilei, knowledge was confined to the aristocracy until Galileo set it free by writing in the language of Federzoni, and this is precisely what the real-life Luther had done with the Bible one hundred years before the period in which Leben des Galilei is set.

The parallel between Brecht's Galileo and Martin Luther exists because it traces the natural course of events, both in the case of Luther and in Brecht's play. In other words, this is a parallel that had to be there in the text, whether Brecht wrote it with intention or not. The parallel between Galileo and Martin Luther breaks down, of course, when Cosmo de Medici hands over Galileo to the Inquisition. The reason why the parallel can break down at that point is that the House of Medici, being itself one of the three heads of the monster of authority in Leben des Galilei, can, at pleasure, deny the events their natural course. Indeed, the reason why it is possible, even easy, to show authority as an antagonist is that authority has the power to, and often does, act antinaturally, thus becoming the natural antagonist.

Besides his attitude toward the Church, Brecht also continually addressed the theme of sensual pleasures as a driving force in the character of his Galileo: "Galilei ist natürlich kein Falstaff: als überzeugter Materialist besteht er auf physischen Freuden” 
(Brecht, "Das sinnliche in Galilei;" see also Brecht, "The Sensual Element in Galileo," 218). The play repeatedly emphasizes that Galileo is human, not a hero, and one way the play emphasizes Galileo's humanity is by pointing out the protagonist's partiality to good food. The "physische Freuden" Brecht means are, however, not limited to things like good food and good wine, but are to be understood in an extended sense: "[W]ichtig ist, daß er auf sinnlicher Weise arbeitet" (Brecht, "Das sinnliche in Galilei," italicization Brecht's; see also Brecht, "The Sensual Element in Galileo," 218) — the good food can, once again, be read as a symbol, specifically, as a symbol of Galileo's scientific work. Sensuality is both a marker of Galileo's humanity, i.e. lack of super-humanity, and one of his defining characteristics.

Then again, science is not the only thing symbolized by the good food of which Galileo is fond: “[D]ann gibt es in seinem Reden Stellen, wo er gute Wörter auswählt und sie abschmeckt wie Gewürze" (Brecht, "Das sinnliche in Galilei;" see also Brecht, "The Sensual Element in Galileo," 219). Sensual pleasure-especially the pleasure of the gustatory sense - is very much a defining feature of Galileo's character. More explicitly, anything can, potentially, be a source of sensual pleasure to him-and, therefore, sensual pleasure means everything to him. This means Galileo can almost be read as a personification, a concrete manifestation of sensual pleasure.

A later critical reading develops this theme of sensual pleasure in Leben des Galilei even further by means of a "fusion" of the acts of seeing and eating (Suvin 190). Brecht himself equates scientific research with sex in elsewhere: "Der Forschungstrieb [ist] kaum weniger lustvoll oder diktatorisch wie der Zeugungstrieb" (Brecht, "Preis oder Verdammung des Galilei?" 13, see also Brecht, "Praise or Condemnation of Galileo?" 
225). The particular equation Suvin suggests is, however, of a different nature, because the two actions that Suvin is condensing together are both already directly represented in the text. The equation of seeing and eating can only mean that the two actions must be read as being interchangeable — seeing and eating can, throughout the text, each be read as a symbol of the other.

The "seeing" that takes place in Leben des Galilei is, of course, the seeing of the heavens — or, rather, the seeing through of the heavens—-that happens through the telescope. Galileo, being the master of the telescope, is the pioneer of seeing, is one who sees more, sees better, and, more importantly, sees "right" (Suvin 190-191), which should, then, justify his prodigious appetite for good food as well. Furthermore, "[i]t should be noted that this alimentary parallel to gaping - the Brechtian fressen famous from The Threepenny Opera but as important in some other plays—is here judged positively, the reverse of glotzen" (Suvin 196, see also Torby 96), and the positive evaluation of consumption can serve to completely invert the meaning of the insults that Andrea hurls at Galileo in the antepenultimate scene, turning Weinschlauch and Schneckenfresser from condemnation into praise. In this way, the equation of seeing and eating in Leben des Galilei turns damnation into praise - a thing into its opposite.

Beyond the theme of role of the Church and the theme of Galileo's indulgence in sensual pleasure, another subplot that haunts the play is the historical theme of exile-in fact, it has been called a "hidden theme" (Stern 110), yet even this hidden theme has several faces: "Four aspects of the exile experience appear in the drama: the refugees' flight from Germany, their economic straits, loss of identity, and intellectual suppression" (Stern 111). A quick demonstration of the four aspects Stern enumerates is in order. 
First, in scene 11 of the 1955 version, Galileo first contemplates going away to Sargedo in Padua, then receives an offer from Vanni of a carriage and horses to escape to Venice, and finally, after being snubbed by Cosmo de Medici, is about to escape from Florence at once-all of these images from Renaissance Italy can be images of refugees trying to leave Nazi Germany (Stern 111-112). Loss of identity appears in the same scene, first when Gaffone fails to acknowledge Galileo, and again when Cosmo de Medici snubs Galileo. The economic plight of refugees is prominent when Priuli's suggests, in the opening scene of the 1955 version, that Galileo might accept the low salary in Venice in exchange protection from the Inquisition (Stern 112-113). And the intellectual suppression is, of course, seen first in Galileo's eight years of silence before Cardinal Barberini becomes the new pope, then, conclusively, in Galileo's house arrest in the penultimate scene of the 1955 version. Stern's four aspects combine to make sure that Galileo remains an eternal outsider through the play's fifteen scenes. Curiously, many of the brief allusions to flight and exile were cut in the second (American) version, which Brecht prepared in collaboration with Charles Laughton, who had no personal experience of either flight or political exile. Laughton's point was that the allusions did not always help advance the narrative. This, by the way, might be a reason why exile remains a minor theme: Because the allusions to exile are not indispensable to the plot, the mind of a reader who fails to register those allusions does not skip a beat. The allusions to flight and exile were all subsequently restored in the final version (Stern 115-116). The fact that Brecht restored the allusions in 1955 suggests that he must have been conscious of the hidden theme of flight and exile, restoring them, on purpose, for the sake of the effect they had - the effect of adding an extra layer of human experience to the play. The 
themes of flight and exile do not move the plot forward, but they serve to keep Galileo from becoming a super-human hero. The themes also serve to keep Galileo an outsider throughout the play, which contributes Galileo's lack of identification with the interests of any authority throughout the play. Galileo must remain independent, yet he must not become a hero, but rather remain independent while being only human. This is only possible because he is an outsider-outsiders, even human ones, are always independent because they never belong - and Galileo remains outsider because of the hidden themes of flight and exile.

A more prominent theme than flight and exile is the theme of Marxism in Leben des Galilei. Several features of the play quite plainly make Marxist statements, such as the great amount of care Brecht takes to "pit the dominant ideology of the Church, which controls the means of production of the peasants of Campagna - and therefore controls theological scientific truth — against the potentially revolutionary scientific truth discovered, but not controlled by Galileo" (Caldwell 40). It is, of course, Brecht's own point again that the Church is a symbol of authority and the play is the account of a revolution suppressed by the authority. But Caldwell places the focus upon the Churchauthority's control over the means of production, and upon class struggle, specifically represented by the struggle of the peasants of Campagna against the Church. Again, the refusal of the Florentine scholars to even look through the telescope in the fourth scene can be interpreted as the resistance of the privileged class to anything that might jeopardize its privilege in the social order (Squiers, "Visibility, Divisibility and the Language of Revolution: a Brechtian Perspective," 40), which is a frequently recurring point in Brecht (Squiers, "A Short Organum on Ideology: Brecht on the Bourgeois 
Weltanschauung," 45). Indeed, the whole play is a series of illustrations of various aspects of mid-twentieth-century Marxist theory (Borchardt 155-159). The play's relationship to Marxism is, however, problematic, because Leben des Galilei also runs counter to Marxist thought in at least one way: "Es entspricht nicht der marxistischen Lehre, daß Brecht in seinem Galilei einem einzelnen, einem `Helden`, eine so entscheidende Rolle für den Gang der Geschichte zuerkennt" (Rohrmoser, "Brecht · Das Leben des Galilei," 412, see also Rohrmoser, "Brecht's Galileo," 124) — the very idea of a powerful protagonist is a step in the direction of a cult of personality, and, therefore, runs contrary to Marxist teachings. Thus Leben des Galilei foregrounds both Marxist teachings and the counter-Marxist feature of a powerful protagonist. This type of complication — contradictory themes in the same text—is not unique to Leben des Galilei as a dramatic technique in Brecht: In Aufstieg und Fall der Stadt Mahagonny (1930; Brecht, Die Stücke von Bertolt Brecht in einem Band, 203-226), for example, he writes both bourgeois and anarchist features into his absurdist text, then proceeding to satirize both of them (Melchinger, "Mahagonny als Mysterienspiel," 32-33). Such incorporation of contradictory themes in the same play serves to build a dialectic within the play. Along with the dialogue between Marxist teachings and the counter-Marxist concept of a powerful protagonist, Brecht leaves open the possibility of an anti-Stalinist reading of Leben des Galilei:

[I]f Oppenheimer's acquiescence in the making of the bomb comes to be suggested by Galileo's renunciation and submission to the power of the Church, surely a number of other topical analogies can also be found: the most obvious (yet the least mentioned, no doubt for all kinds of reasons, although Brecht 
himself mentions it) is the submission of Bukharin in Stalin's show trials.

(Jameson, Brecht and Method, 154)

Another article reports about the American version that, "Als [Galileo] in New York aufgeführt wurde, war man in Versuchung sich einzureden, daß Brecht Anti-Stalinist geworden sei” (Arendt, "Der Dichter Bertolt Brecht,” 56; see also Arendt, "The Poet Bertolt Brecht," 45). And Leben des Galilei has also been read as an account of Nazism in Germany in the following way:

Wie gefährlich die präzise Allgemeinheit der Dichtkunst ist, läßt sich am besten an einem seiner neuesten Theaterstücke, dem Galilei nachweisen, in dem der Forscher beschrieben wird, der etwas entdeckt hat (die Erde dreht sich um die Sonne), was den Lehren eines autoritären Herrschaftsapparates zuwiderläuft (der katholischen Kirche und der Inquisition). Es ist keine Frage, daß dieses Drama mit gleicher Genauigkeit auf die Nazi-Diktatur wie auf die bolschewistische Diktatur paßt. (Arendt, "Der Dichter Bertolt Brecht," 56; see also Arendt, “The Poet Bertolt Brecht," 45)

This, of course, is the auxiliary theme, discussed by Brecht himself, that the Church in Leben des Galilei can be a symbol of any figure or institution of authority. Brecht keeps the symbol sufficiently ambiguous for the play to function either as a condemnation of Hitler or as a condemnation of Stalin.

The anti-authoritarianism, as well as the wide assortment of other auxiliary themes - such as the theme of flight and exile, or the equation of seeing, eating, and knowledge — serve the purpose of making Leben des Galilei a complex, multidimensional text. Without the interplay of the minor themes, it may have run the risk of 
devolving into a naïve, if still powerful, text of protest against nuclear arms. As it stands, it is a tableau of a deeply divided, lethally conflicted world. Its function is to offer the reader the momentary luxury of viewing that world from the outside, as though witnessing a catastrophe from the exile, along the axis of time, of 300 years from the scene of the catastrophe. And Brecht's play, Leben des Galilei, becomes the telescope through which the reader can see-and know_from so great a removal. 


\section{CHAPTER THREE: THE INTERTEXTUALITY OF LEBEN DES GALILEI}

This chapter analyzes Leben des Galilei in immediate relation to three different groups of other texts. Opposing Leben des Galilei to other texts sheds light on the ways in which it differs from those plays, throwing into relief things it is not, thus simultaneously highlighting things it is. The first section studies Leben des Galilei in opposition to two plays, one by Friedrich Dürrenmatt (1921-1990), the other by Max Frisch (1911-1991). Brecht directly influenced both authors, who may be fairly called his immediate successors as the most significant German-language playwrights (see, for example, Frisch, Biedermann und die Brandstifter, v). The second section proceeds to set Leben des Galilei against other plays of Brecht himself, focusing on one particular way in which Brecht went completely against his own standard procedure when he wrote Leben des Galilei. The final section of this chapter constructs a convergence of the apparently unrelated first and the second sections, suggesting a common structure underlying the observations of those two sections.

\section{BRECHT, FRIEDRICH DÜRRENMATT, MAX FRISCH}

Friedrich Dürrenmatt's Die Physiker was written during 1959-1961 and first produced in 1962 at the Schauspielhaus in Zürich—where the first version of Leben des Galilei had also premiered almost two decades earlier. Die Physiker was also first published in 1962 (Dürrenmatt 94). The play is labelled, already in its title, a comedy. Once, when asked about Die Physiker's relationship to Leben des Galilei, Dürrenmatt replied that he had wanted to write not a tragedy, but rather the satire that is staged before the tragedy (Zimmermann 124). Dürrenmatt's reply may have been itself intended 
satirically, because Brecht had insisted that Leben des Galilei was not a tragedy (Brecht, "Leben des Galilei ist keine Trägodie;" Brecht, "The Life of Galileo Is Not a Tragedy"), and because, elsewhere, Dürrenmatt also wrote that, in his play, the story had been "zu Ende gedacht" (Dürrenmatt 91), which suggests that he intended Die Physiker to be more of a last word than an opening act. In either case, it is certain that Die Physiker was a conscious response to Leben des Galilei.

As a first step toward an independent determination of the relationship between the two plays, here is a brief summary of Die Physiker: The physicist Möbius makes a discovery that can, potentially, cause a catastrophe. He pretends to be insane and lands in an asylum, hoping to keep his discovery from receiving attention and being put to use in a destructive way. Two spies, of different nations, also pretending to be insane-one pretending to think he is Isaac Newton, the other pretending to believe himself to be Albert Einstein—follow Die Physiker's protagonist Möbius to the same asylum, each hoping to get their hands on the new discovery, maybe even to convince Möbius to work further for his nation. However, it is Möbius who convinces both Newton and Einstein to abandon their missions and stay on at the asylum, where they could all continue to pretend insanity while making progress in science without running the risk that their discoveries might harm humanity some day. In a twist ending, the psychiatrist in charge of the asylum, Dr. Mathilde von Zahnd, turns out to be the character who is genuinely insane. She has already acquired the new discovery, and has plans for dominating the world by using it.

The similarities between Die Physiker and Leben des Galilei on the level of the ethics of nuclear physics are obvious. Brecht's Galileo, proposes, in the penultimate 
scene of the 1955 version of Leben des Galilei, a Hippocratic Oath for scientists, that scientists should take it upon themselves to ensure that their work only helps, and never hurts, humanity; Dürrenmatt assumes that scientific research is carried out in secret, but stops short of actively serving destructive forces_-assumes that J. Robert Oppenheimer and the physicists of the Manhattan Project do not build the bomb, that science has, and follows, the Hippocratic Oath Brecht's Galileo had suggested. Then Dürrenmatt asks what would happen if, starting from the assumption, the story is " $\mathrm{zu}$ Ende gedacht".

The differences between the two plays are obvious as well. The ultimate point of the last version of Leben des Galilei is its hope that the envisioned Hippocratic Oath for scientists might actually result in a science that would only do good. Dürrenmatt's answer to his own question is that, in spite of the best efforts of the three physicists, there would always be a catastrophe. The ultimate point of Die Physiker is that - in the words of Möbius_- "Was einmal gedacht wurde, kann nicht mehr zurückgenommen werden” (Dürrenmatt 85). Science is not capable of taking back its discoveries when it senses that they are about to be used for destructive purposes. Once a scientist makes a discovery, he or she no longer has any control of how the discovery is used.

Thus Leben des Galilei and Die Physiker are both sharply critical of scientific ethics—or the lack thereof—but the similarities end there. Die Physiker believes that the situation is beyond all hope of redemption, that it is impossible to have science without also having disastrous consequences of science. Leben des Galilei, in proposing the Hippocratic Oath for scientists (Brecht, Die Stücke von Bertolt Brecht in einem Band, 537), believes that, while fundamental changes in scientific ethics are called for, a purely benevolent science should, ultimately, be possible. While Leben des Galilei does not 
explicitly show such a purely benevolent science on the stage, there is nothing in the text that explicitly rules out such a science either. The possibility remains open: Andrea, for example, could be crossing the border carrying, in his mind, the ideal of a science that would only do good; indeed, Galileo's manuscript could, conceivably, be read as a symbol of its author's express ideal of a benevolent science, a covenant, and Andrea's collusion in smuggling the manuscript out of Italy could, then, be read as a symbol of his accepting Galileo's ideal. Leben des Galilei leaves optimism standing when its curtain falls.

The difference between Leben des Galilei and Die Physiker is, then, one about optimism and pessimism. Friedrich Dürrenmatt's play is critical of science, and explicitly states that there is no hope, no possibility of grace left; Brecht's play leaves open the hope of grace (see, for example, de la Viña 40; see also Haus, "What Can a Galileo Production Reveal?" 131-132), while still emphasizing the massive extent of change that must come about before grace can be attained.

In contrast to Die Physiker, Biedermann und die Brandstifter by Max Frisch (1911-1991) is, in the main arc of its story, not about the atom bomb at all. The text started, in the first half of 1948, as a brief prose piece called "Burleske" (printed in Frisch, Tagebuch 1946-1949, 243-249). A version called Herr Biedermann und die Brandstifter was broadcast as a radio play in March 1953 (Frisch, Biedermann und die Brandstifter, viii); like Galilei and Die Physiker, Biedermann und die Brandstifter too was first produced at the Schauspielhaus in Zürich, premiering on March 29, 1958 (Frisch, Biedermann und die Brandstifter, viii). It was first published as a book the following year (Frisch, Biedermann und die Brandstifter, ix). 
Frisch's play opens with the title character, Biedermann, reading in the newspaper about an unusually large number of incidents of arson. A stranger named Schmitz appears at his door, and Biedermann lets him stay in the attic. Later, another stranger, Eisenring, comes to the house and joins Schmitz in Biedrmann's attic. Soon the attic is full of barrels of petrol. A policeman stops by to inform Biedermann that his former employee, Knechtling, has committed suicide. The policeman asks what is in the barrels, and Biedermann lies, saying that the barrels contain hair tonic. Biedermann does not believe that his house guests could be arsonists—in fact, he even measures out the detonating fuse together with them, thinking it is all just a joke. Schmitz and Eisenring have a third companion, identified only as "ein Dr. Phil.," who matches the stereotype of an academic. Biedermann prepares a lavish dinner for his guests. As a sign of his trust in Schmitz and Eisenring —of his belief that they are not arsonists—Biedermann gives them matches. The pair excuse themselves; the Dr. Phil. makes a speech in which he distances himself from the actions of Schmitz and Eisenring. Then the house explodes, and the resulting fire is so great that the whole town burns down. In the coda, Biedermann has landed in hell after his death, where he learns that Schmitz is Beelzebub and Eisenring is the Devil.

Brecht's relationship to Max Frisch is well-documented. The two playwrights were in contact since the beginning of 1948 (Frisch, Tagebuch 1946-1949, 285), when Brecht, feeling pressed to repatriate to Europe, settled briefly in Switzerland. Frisch read, and was asked his opinion of, an early manuscript of Brecht's theoretical text "Kleines Organon für das Theater" (Frisch, Tagebuch 1946-1949, 292), in which Brecht discusses his seminal theories of theatre, such as epic theatre, Gestus, and Verfremdungseffekt (see 
Brecht, Brecht on Theatre, 179-205). The two men even visited the construction site of Frisch's architectural work, the prizewinning public swimming pool in Letzigraben, early in 1949 (Frisch, Tagebuch 1946-1949, 338). Frisch published an excerpt from his diary entries about Brecht in Die Zeit the following year (as Frisch, "Brecht der Priester"). Another excerpt, translated into English by Carl R. Mueller, appeared as a eulogy after Brecht's death (as Frisch, "Recollections of Brecht"). In the full title of Biedermann und die Brandstifter, Frisch labels his play Ein Lehrstück ohne Lehre—it is a reasonable hypothesis that the term Lehrstück is an allusion to Brecht's 1920s insistence upon the didactic functions of his own theatre. The qualifier ohne Lehre, then, must be an announcement of differences between Brecht's Lehrstücke and Biedermann und die Brandstifter.

The immediate impetus for Biedermann und die Brandstifter may have been the communist takeover of Czechoslovakia (Frisch, Tagebuch 1946-1949, 242-243; see also Frisch, Biedermann und die Brandstifter, viii). However, Frisch kept his text sufficiently ambiguous that it may be read as a representation of other histories as well, such as the rise of Nazism in Germany almost two decades earlier. In the main reading, Biedermann stands for the common man, who, even if well-meaning, is so gullible that he would not suspect anything even when his "house guests" tell him to his face that they are going to set fire to his house. The Dr. Phil. is the intellectual who is, for ideological reasons, with the arsonists at first, and, for ideological reasons again, declines to take any share of the responsibility for the arson and its consequences at the end. In this main reading, Biedermann und die Brandstifter has, content-wise, no clear relationship to Leben des Galilei. 
But the ambiguous nature of Biedermann und die Brandstifter allows for variant, secondary readings, such as for reading the Dr. Phil. as a physicist who first works with Schmitz and Eisenring because he hopes that the work will benefit the world—Eisenring calls the Dr. Phil. "Weltverbesserer," and adds, "[E]uresgleichen ist immer so ideologisch, immer so Ernst, bis es reicht zum Verrat" (Frisch, Biedermann und die Brandstifter, 92). If the Dr. Phil. is a physicist, then, of course, he can be compared with Galileo, and also with Dürrenmatt's Möbius, and even with real-life nuclear physicists, such as Oppenheimer.

At the end of Biedermann und die Brandstifter, with the explosion imminent, the Dr. Phil. says as much in his own defence, adding that he had not known the motives of Schmitz and Eisenring: "Sehen Sie, Herr Biedermann, ich was ein Weltverbesserer, ein ernster und ehrlicher, ich habe alles gewußt, was sie auf dem Dachboden machten, alles, nur das eine nicht: Die Machen es aus purer Lust!"' (Frisch, Biedermann und die Brandstifter, 133). Thus Max Frisch's Dr. Phil. absolves himself from any obligation to answer for the consequences by simply saying, at the last moment, "Ich distanziere mich-" (Frisch, Biedermann und die Brandstifter, 132). The reading of the Dr. Phil. as representing modern physics is supported by the fact that the play ends with a series of explosions: "Es folgt eine Serie von Detonationen fürchterlicher Art" (Frisch, Biedermann und die Brandstifter, 134).

The difference between Leben des Galilei and Biedermann und die Brandstifter is, again, a matter of unadulterated pessimism in Frisch, where Brecht left open the possibility of hope for the future (de la Viña 40; Haus, "What Can a Galileo Production Reveal?" 131-132). Indeed, Frisch is, if possible, even darker than Dürrenmatt, since 
Schmitz and Eisenring in Frisch's Biedermann und die Brandstifter act "aus purer Lust," where Frau von Zahnd in Dürrenmatt's Die Physiker was insane. And the bleak, cynical vision is characteristic of Frisch's writing in general: “One idea that recurs throughout Frisch's work is that man will not profit by experience. There is therefore a note of despair in his work which is not dispelled by his sharp ironic wit and his use of the grotesque and burlesque" (Frisch, Biedermann und die Brandstifter, v). Brecht, in contrast, refused to leave the world of Leben des Galilei completely devoid of hopewhile showing on his stage, too, the world's desperate state, he also makes sure to give his world a measure of Marxist optimism, saying that things could be better, and even saying what must change in order for things to become better.

The difference—Brecht's relative optimism against other contemporary playwrights' pure pessimism — was not restricted to German-language theatre. A discussion among several writers and critics that set Brecht—not just Leben des Galilei, but his work in general —against the absurdist plays La Leçon (1951) and Les Chaises (1952) by Eugène Ionesco (1909-1994) made, among other observations, the same remark: “[D]ie einen gäben die Partie grundsätzlich verloren, die anderen hielten - ohne die Schwierigkeit der Situation zu verkennen - an der Hoffnung fest (Tynan et al 27, see also Ionesco 87-108). The absurdists gave up the game as fundamentally lost, but Brecht's epic theatre held on to hope. Beyond the playwrights, the theatre-going public of the mid-to-late 1950s, in the U.S.A. at least, also seems to have favoured the pure pessimism of absurdist theatre (Weisstein 374).

And it was not just among playwrights and theatre-lovers that Brecht's optimism — however reserved, however carefully qualified — was unique. The Russell- 
Einstein Manifesto, dated July 9, 1955, was written by Bertrand Russell and signed by Russell himself, by Albert Einstein, and by nine other eminent intellectuals. It culminates in the following resolution:

In view of the fact that in any future world war nuclear weapons will certainly be employed, and that such weapons threaten the continued existence of mankind, we urge the governments of the world to realize, and to acknowledge publicly, that their purpose cannot be furthered by a world war, and we urge them, consequently, to find peaceful means for the settlement of all matters of dispute between them. (Born et al)

That is, the illustrious signatories of the manifesto, all of them luminaries of science and philosophy, could come up with no good response to the threat of nuclear warfare, and was reduced to begging the world powers that they should, in future, refrain from war. The problem of the mushroom cloud lurking at the horizon was also considered, the same month, at the annual conference of Nobel Laureates at Lindau, and there too a desperate plea for peace appeared to be the only solution: "Alle Nationen müssen zu der Entscheidung kommen, freiwillig auf die Gewalt als letztes Mittel der Politik zu verzichten. Sind sie dazu nicht bereit, so werden sie aufhören, zu existieren” (Alder et al). The world's greatest scientists and intellectuals addressed the problem of the atom bomb in 1955, and they reached the same conclusion as Möbius in Dürrenmatt's Die Physiker, that "Was einmal gedacht wurde, kann nicht mehr zurückgenommen werden." Having built the bomb, they were incapable of taking it back. They were in the power of the political authorities that were in possession of the bomb, and the world's survival depended upon the unreliable goodwill of those political authorities in times of war. 
The question, then, is this: How could Brecht — in spite of the reality of the bomb, when neither science, nor art could see a way out - still continue to write a measure of hope into Leben des Galilei? By what means, what technique did he work his miracle of optimism?

\section{THE CLASSICAL MISE EN ABYME}

The analysis in this section—of Leben des Galilei in a very specific comparison with Brecht's other work - must appear, for the moment, to be completely unrelated with all preceding discussion in this thesis. The next section, however, constructs a convergence of the present section with the previous one about the difference along the optimism-pessimism axis between Leben des Galilei and other texts contemporary with it.

In Leben des Galilei, Brecht explicitly alludes to Horace's Satire 1.8 in scenes 8 and 12 of the 1955 version, and mentions Horace by name a third time in the penultimate scene. The satire is quoted in the appendix to this thesis; the 1760 English prose translation of Christopher Smart (1722-1771) is as follows:

Formerly I was the trunk of a wild fig-tree, an useless log: when the artificer, in doubt whether he should make a stool or a Priapus of me, determined at last that I should be a God. Henceforward I became a God, the greatest terror of thieves and birds: for my right hand restrains thieves, and a bloody-looking pole is stretched out from my frightful middle; but a reed fixed upon the crown of my head terrifies the mischievous birds, and hinders them from settling in these new gardens. Before this, the fellow-slave bore dead corpses thrown out of their narrow cells to 
this place, in order to be deposited in paltry coffins. This place stood a common sepulchre for the miserable mob, for the buffoon Pantolabus, and for Nomentanus the rake. Here a column assigned a thousand feet of ground in front, and three hundred towards the fields; that the burial-place should not descend to the heirs of the estate. Now one may live in the Esquiliæ, since it is made an healthy place, and walk upon an open terrass; where lately the melancholy passengers beheld the ground frightful with white bones: tho' both the thieves and wild beasts used to infest this place, put together, do not occasion me so much care and trouble, as do these hags, that turn people's minds by their incantations and drugs. These I cannot by any means destroy nor hinder, but that they will gather bones and noxious herbs, as soon as the fleeting moon has shewn forth her beauteous face. I myself saw Canidia, with her sable garment tucked up, walk with bare feet and disheveled hair, yelling together with the elder Sagana. Paleness had render'd each of them horrible to behold. They began to claw up the earth with their nails, and to tear a black ewe-lamb to pieces with their teeth. The blood was poured into a ditch, that from thence they might charm out the shades of the dead, ghosts that were to give them answers. There was a woollen effigy too, another of wax; the woollen one larger, which was to inflict some sort of punishment on the little one of wax. The waxen stood in a suppliant posture, as ready to perish in a servile manner. One of the hags invokes Hecate, the other fell Tisiphone. Then might you see serpents and infernal bitches crawl about them; and the moon with blushes withdrawing behind the lofty monuments, that she might not be a witness to these infamous doings.-But if I lie, even a little, about this affair, may my 
head be contaminated with the white filth of ravens; and may Julius, and the effeminate Miss Pediatius, and the knave Voranus come to urine upon me and befoul me. Why should I mention every particular? viz. in what manner, speaking alternately with Sagana, the ghosts uttered dismal and piercing shrieks; and how clandestinely they hid in the earth a wolf's beard, with the teeth of a spotted snake; and how great a blaze flamed forth from the waxen image? And how I was shocked at the voices and actions of these two furies, a spectator however by no means incapable of revenge? For from my cleft bum of fig-tree I let a fart, which made as great an explosion as a bursten bladder. But they immediately ran into the city: and then, with exceeding laughter and diversion might you have seen Canidia's artificial teeth, and Sagana's towering tete of false hair falling off, and the herbs, and the inchanted bracelets from her arms. (Horace 69, 71)

Leben des Galilei is unique in Brecht's æeuvre in the amount of care the playwright takes to explicitly attribute the above satire to its original source. Brecht's usual practice is to make free use of other texts in his plays, without comment or apology. He constructs his texts, as a matter of course, out of pre-existing texts. One critic even suggests that "everything in Brecht is plagiarism in one way or another - whether from past or present, from other people or classics" (Jameson, Brecht and Method, 133). One of Brecht's main methods of working was to freely re-invent material from any source that might serve his purpose at the moment.

Such practice, of course, is nothing unusual, because any text, not just those of Brecht, "is constructed out of already existent discourse. Authors do not create their texts from their own original minds, but rather compile them from pre-existent texts" (Allen 
35). All texts are "plagiarism in one way or another." Indeed, the line of argument has been drawn further:

"[Roland] Barthes develops this point into a recognition that the origin of the text is not a unified authorial consciousness but a plurality of voices, of other words, other utterances and other texts. If we were able to look inside the head of the author - something traditional literary criticism believes is possible by interpreting the literary work - then, Barthes's argument implies, we would not discover original thought or even uniquely intended meaning, but what he styles as the 'already-read', the 'already-written'. (Allen 70)

Thus the author-and this applies absolutely to Brecht—is confined to the intertext, with no chance of gaining any degree of freedom. It is possible for an author to be blissfully ignorant of this confinement, and the alternative is for an author to be aware of his or her confinement; in the latter case, the author must accept the fact of the confinementresign himself or herself to it - and continue working, continue producing text, within the limits of the confinement. In either case, the only thing the author-even Brecht—can do is to keep rewriting the intertext, and it is usual practice-in particular, it is usual for Brecht—to simply rewrite the intertext.

It is less usual, then, to explicitly name a text's sources within the text itself (see Grimm, Bertolt Brecht: Die Struktur seines Werkes, 42-49 for a discussion of Brecht and his intertext). Yet this is what Brecht does with Horace's Satire 1.8 in Leben des Galilei.

The satire was not a late addition to the play—Brecht already explicitly names Horace in the 1938 outline (called version zero in chapter one above) of Leben des Galilei, and he retains the explicit allusion in every version, even in the American 
version, in which, like much of the play, Galileo's speech about Horace was drastically shortened. In the final version, Galileo's speech-in scene 8, as part of his conversation the short monk—is fully developed (Brecht, Die Stücke von Bertolt Brecht in einem Band, 519), and, in scene 13, just before Galileo recants and returns, the short monk recounts the allusion to the rest of the party waiting to learn the outcome of the inquisition (Brecht, Die Stücke von Bertolt Brecht in einem Band, 531). And, for good measure, Horace's name is even mentioned again — for the third time — in the following scene, in which Galileo says to Virginia, "Ich fühle mich nicht wohl genug. Lies mir etwas Horaz" (Brecht, Die Stücke von Bertolt Brecht in einem Band, 533). It is reasonable to infer that Brecht wanted to make sure that his readers would take note of the allusion, which could be the reason why he, contrary to usual practice, explicitly named his source.

If Brecht did indeed make an effort to ensure that his readers would not miss the allusion, then a close look at the relation between Brecht's play and Horace's satire is in order. The point of Brecht's allusion to Horace is that the satire has quite a few interesting parallels with Leben des Galilei. First, Priapus, the satire's narrator, corresponds to Galileo. To see this, notice, first, that the satire's Priapus is confined in his stump of fig-wood; in Brecht's play, Galileo is confined by the Inquisition. Thus Priapus in the satire and Galileo in the play appear in similar forms - and a character's form of appearance is one of his or her distinguishing features (Propp 84-86). Another distinguishing feature of a character is his or her set of attributes (Propp 87-91), and Priapus and Galileo also have similar attributes. The main attribute of Priapus is that "a bloody-looking pole is stretched out from [his] frightful middle" (Horace 69)—a 
phallus - and this parallels the theme of sensual pleasure as a defining characteristic of Galileo. Indeed, recall, from chapter two above, that Suvin equated Galileo's appetite for food with his insatiable hunger for knowledge; recall, too, that Brecht himself equated Galileo's urge for knowledge directly with sex (Brecht, “Preis oder Verdammung des Galilei?” 13, see also Brecht, "Praise or Condemnation of Galileo?” 225). Finally, Galileo's appetite for food is an inversion of the final, decisive fart of Priapus in the satire. Thus Brecht's Galileo and Horace's Priapus have two things in common: first, confinement as a form of appearance; second, sensual pleasure as a character attribute. There is even a parallel between Horace's satire and the main subject matter of Leben des Galilei, since Priapus's “fart, which made as great an explosion as a bursten bladder" (Horace 71) can be equated with the explosion of a bomb.

According to the Russian formalists, two characters from two different texts can, under three specific conditions, be identified with each other. Two of the three conditions are that, first, the characters should appear in their respective texts in the same way (Propp 84-86), and second, that the characters should share a common attribute (Propp 87-91) — the common attribute can then serve as a metonymy for each of the two characters in his or her respective text, thus making them equal each other because they both equal, by metonymy, their shared attribute. The previous paragraph demonstrates that Brecht's Galileo and Horace's Priapus have both a form of appearance and an attribute in common.

But forms of appearance and attributes are merely the minor conditions for identifying characters. The ultimate defining feature of a character is the function he or she performs in his or her text (Propp 25 et seq.). In the satire, Priapus has the function 
of keeping the witches (and thieves, etc.) out of the garden. In Leben des Galilei, the functional parallel is more complicated. In scene nine of the final version, Galileo first easily dismisses Mucius, then sends away Ludovico — the scene ends with Virginia accusing Galileo, "Du hast ihn weggeschickt, Vater!" (Brecht, Die Stücke von Bertolt Brecht in einem Band, 525). And, just as Priapus chases away the thieves by virtue of his phallus, Galileo vanquishes Mucius and Ludovico by the strength of his knowledge — his knowledge, which is one of his several attributes that can be read as being an equivalent of Priapus's phallus (Brecht, "Preis oder Verdammung des Galilei?” 13, see also Brecht, “Praise or Condemnation of Galileo?” 225). However, Galileo's knowledge alone cannot defeat the Church and the Inquisition, just as Priapus's phallus alone is not enough to keep Canidia and Sagana out of the garden.

This last sentence suggests that religious authority in Leben des Galilei is to be equated with the witches in Horace's satire, and it may be well to briefly justify this equation. In Horace, the witches "turn people's minds by their incantations and drugs" (Horace 69), and, in Brecht, the Church's ultimate function is to keep the peasants in line by manipulating them with faith, which are clear parallels. Again, Horace's two witches engage with several animals for their witchcraft (Horace 71), and Brecht's Cardinal Bellarmine and Cardinal Barberini wear animal costumes in scene seven, the ball scene, where a quick comparison of the play's three versions shows that Brecht deliberated upon the specific animal each Cardinal was to be. Finally, the witches have "a woolen effigy too, another of wax; the woolen one larger, which was to inflict some sort of punishment on the little one of wax. The waxen stood in a suppliant posture, as ready to perish in a servile manner" (Horace 71) — up to here, the description could easily be any generic act 
of oppression. The reading becomes more specific, though, when, after the witches perform a ritual, "how great a blaze flamed forth from the waxen image" (Horace 71) - it is at least a possibility that the woollen effigy is the Inquisition, the wax effigy is an alleged heretic, and the witches' play is parallel to the Inquisition first torturing the alleged heretic, then burning him or her at the stake.

Returning to Priapus and Galileo, the parallel between Horace's satire and Brecht's play becomes complicated when it comes to the two characters' responses to their respective problems. Priapus's stump of fig wood explodes open at a crack—his wooden body is damaged — and the explosion drives off the witches. Galileo, in contrast, does not take the opportunity to overthrow the Church, electing instead to keep his body intact. This is one way of looking at the comparison, and this reading of the comparison serves to drive home the text's criticism of Galileo's choice by showing Galileo side to side with the image of Priapus, who fulfils his function in Satire 1.8 by sacrificing his wooden body. In the reading of Leben des Galilei as a metaphorical account of modern physics, the physicists' choice leads to the bomb being dropped, resulting in an explosion, just as Priapus's fart is explosive.

However, there is another way of looking at the comparison between Priapus's explosion and Galileo's recantation — there are two different possible readings at this point. One reading is discussed in the previous paragraph; in the alternative reading, Galileo does perform a sacrifice, but he sacrifices his self-esteem instead of his bodyhis ego instead of his physical well-being; the play, being a product of the twentieth century, has an open ending, where, in exchange of Galileo's sacrifice, his book crosses the border with Andrea, giving rise to the possibility that science might flourish again 
some day. In this alternative reading, Horace's satire and Leben des Galilei are convergent to their very ends.

There is, as well, a completely different level on which Priapus in Horace's satire and Galileo in Brecht's play serve the same function: They might both be standing in for their respective authors. It is possible to read Priapus as Horace himself (see Sharland), and Brecht certainly seems to use Galileo as his own voice at several points in the play. One definite example of this is Galileo's line about the Hippocratic Oath for scientists in the penultimate scene of the 1955 version; in many other exchanges that end with Galileo having the last word - such as, at the end of scene 13, the recantation scene, "Unglücklich das Land, das Helden nötig hat" (Brecht, Die Stücke von Bertolt Brecht in einem Band, 532) — the last word might be what Brecht himself wants to say. Thus Brecht's Galileo might equal Horace's Priapus because each character, in his respective text, serves the purpose, external to their respective narratives, of giving voice to the opinions of their respective authors.

One final point: Horace was an Epicurean —indeed, he was the author of the Epicurean motto carpe diem. Interestingly enough, Galileo's personal philosophy, as far as it is evident in Leben des Galilei, matches Epicureanism in several aspects, such as the aversion to physical pain.

In summary, the satire that Brecht embeds so prominently in the play-by explicitly naming Horace three times, in stark contrast to the Brechtian usual practice of what can be called "plagiarism" (Jameson, Brecht and Method, 133) — is a replica of the play on the smaller scale of 50 lines of Latin verse, because Brecht's Galileo can be equated, using the parameters developed by Propp for equating characters from different 
texts, with Horace's Priapus. Horace's Satire 1.8 is a scale model of Leben des Galilei, only with the closing section inverted, as in a mirror reflection, if Priapus's explosion is read as being parallel to Galileo's recantation. If, instead, Priapus's explosion is understood to be parallel to Galileo's self-condemnation in the penultimate scene, then the satire and the play are exact replicas, only differing in scale; in a darker reading, Priapus's explosion can even be read as the explosion of an atom bomb.

The parallel between the two texts, as a structural feature, is amenable to interpretation in two ways. First, it is possible to read the play as an extended adaptation of the satire; second, it allows the satire to be read as a mise en abyme, an image of the play, embedded in the play (Chambers 32 et seq.), which calls to mind the sequence of progressively smaller images in a pair of parallel mirrors.

\section{THE MYTHIC CONNECTION}

The two previous sections both ended with observations that call for further interpretation. The first, comparing Leben des Galilei with texts in which other playwrights addressed the problem of the atom bomb, asked by what means Brecht manages to generate a measure of hope in his play; the second, comparing Leben des Galilei with other texts by Brecht himself, asks why Brecht takes such great care to foreground the parallel between his play and Horace's Satire 1.8, and why he, contrary to his own practice, makes an effort to ensure that his readers would not miss his allusion to Horace.

The two questions have, on the surface at least, nothing in common beyond both being questions about Leben des Galilei and both stemming from comparisons of Leben 
des Galilei with other texts. The two groups of texts chosen for comparison in the two sections are entirely different, and, unsurprisingly, the two resulting questions appear to go off in entirely different directions. The goal of this section is to construct a convergence of the apparently unrelated questions of the two previous sections. The convergence consists in a possible common answer to the two questions. The possible common answer comes from a comparison with a third, different group of texts: a cycle of Native American myths.

The cycle of myths in question is a large body of narratives, collected from various tribes throughout both Americas, that are likely to be different surviving fragments of a "long native Genesis" (Lévi-Strauss 16). The full version of the original myth being a matter of conjecture, and the surviving fragments, as related by LéviStrauss, being several in number, only one representative version is outlined below, with emphasis on the aspects essential for the comparison with Leben des Galilei. Further details, as well as variations, are added where relevant in the remainder of this section.

The cycle of myths at question here is about the origin of potters' clay, and features a bird species, the goatsucker, as protagonist. In the version according to the Jivaro, who are traditionally head-hunters and now inhabit the border between Ecuador and Peru, the goatsucker, Aôho, used to be a woman. She was married to both the Sun and the Moon, but favoured the Sun. The Moon, taking offence at this, climbed up to the sky on a vine and eclipsed the Sun by blowing on him. Aôho, in danger of losing both her husbands, followed the Moon up the vine, carrying a basketful of clay. The Moon cut the vine in order to get rid of Aôho, who turned into the bird as we know it today. The clay, which was then scattered everywhere, became potters' clay (Lévi-Strauss 14). 
In the previous section, an application of Propp's three parameters-functions, forms of appearance, and attributes—-led to an identity between Brecht's Galileo and Hprace's Priapus. The same method will now extend the identification to also equate the Jivaro goatsucker with both Galileo and Priapus. The main defining feature of any character, according to Propp, is the function he or she performs in the plot (Propp 25 et seq.); in the Jivaro myth, the goatsucker's function is to bring potters' clay to mankind: “The clay used in ceremonial jars comes from Aôho's soul, and women gather it from the places where she dropped it during her fall, when she was quickly changing into a Goatsucker" (Lévi-Strauss 15). This parallels both Priapus' function of securing the garden, i.e. a plot of land, from the witches in Horace's Satire 1.8, and Galileo's function of establishing the true nature of the planet earth for mankind in Leben des Galilei.

The functional comparison between Brecht's play, Horace's satire, and the Jivaro myth extend even further. Priapus secures the garden by means of an explosive fart, which is sufficiently associated with annihilation to drive away the two witches. Galileo, as discussed in the previous section, acts contrarily, in that he abdicates his function of securing the truth about earth and sky, thus preventing self-annihilation, but, in exchange, also passing up his opportunity to annihilate the authority; in the alternative reading, Galileo secures his physical body by annihilating his self-esteem; in the metaphorical reading, it is the earth that is annihilated, and the annihilation is caused by the bomb. The goatsucker of the Jivaro myth does the exact opposite, because it is an origin myth, which is the opposite of annihilation. And, while it does not directly address the creation of the world, it is about the origin of potter's clay, which is made of the same material as the world. 
While a character's plot function is his or her main defining feature, it is not the only one. A second defining feature is the way the character appears in the narrative (Propp 84-86). As pointed out in the previous section, Galileo's ultimate form of appearance in Leben des Galilei is confinement in house arrest by the Inquisition, and Priapus' initial form of appearance in Satire 1.8 is confinement in the stump of fig wood. In comparison, the goatsucker in the Jivaro myth is ultimately confined to the earthaway from the sky, because "Moon saw her, and, to get rid of her forever, he cut the vine that was linking the two worlds [of earth and sky]" (Lévi-Strauss 14). Thus the Jivaro goatsucker matches both Brecht's Galileo and Horace's Priapus not only in function, but also in form of appearance.

The third and final defining feature of a character is his or her set of attributes (Propp 87-91). These could include both physical attributes and accessories-objects associated with the character-which can all combine to together define the character by metonymy. The previous section's comparison between Leben des Galilei and Satire 1.8 is more complicated when it comes to attributes than it is for either functions or forms of appearance, because Galileo in Brecht's play and Priapus in Horace's poem have not identical, but related and opposite attributes - Galileo has a prodigious appetite, "Galilei aß gern gut” (Brecht, Die Stücke von Bertolt Brecht in einem Band, 499), whereas Priapus emits a loud fart to frighten away the witches Canidia and Sagana. But a comparison of the texts of Brecht and Horace with the goatsucker cycle provides a resolution of the opposition, because the goatsucker is, in different parts of the cycle, endowed with both of the attributes. Appetite as an attribute of the goatsucker is, in fact, highlighted in the cycle_- "The mythology draws ... especially on [the goatsucker's] 
grasping and gluttonous nature, displayed in three kinds of appetites or feelings: avarice, jealousy, and envy, which are often designated by the same name in the languages of the so-called primitive people" (Lévi-Strauss 35), which establishes an equation between the goatsucker and Brecht's Galileo. The connection with Priapus is best established by considering a group of North American variations on the myth:

"[T]hey all start with a quarrel between the Trickster (a deceiving half-god) and a rock endowed with speech and movement. The causes of the quarrel do not vary much from one version to the next: the Trickster has given his blanket, his shirt, or his knife to the rock and now wants them back because it is about to rain or because he needs the knife to cut his meat; the Trickster had given the rock a blanket soiled with excrement, but, now that it has been cleaned by its new owner, he would like to have it back; the Trickster steals the blanket from the rock or else he relieves himself on the rock and soils it. The rock has no use for robbers or litterers. He also thinks that one cannot give something and then take it back. The Blackfoot version contains the following maxim: "What was given to the great rocks can never be taken back." So the rock starts rolling, chasing after the Trickster, catches up with him, and traps him under his huge weight. Summoned by the cries of the victim, several animals come to his rescue, but they all get killed by the rock; or else the victim calls directly to the Goatsuckers (...). The last bird he implores manages to shatter the rock, almost always by farting violently. (Lévi-Strauss 65)

Both Priapus in Horace's Satire 1.8 and the goatsucker solve the problems in their respective texts by farting, which establishes their equation, and this equation completes 
the identification of Leben des Galilei, Satire 1.8, and the goatsucker myth cycle. In fact, the North American version also features a direct connection between the goatsucker's violent fart and the atom bomb in the metaphorical reading of Leben des Galilei. In summary, the three protagonists—Brecht's Galileo, Horace's Priapus, and the goatsucker in the cycle of Native American myths - are identical in Propp's three criteria of function, form of appearance, and attribute.

Curiously, the North American version even includes a parallel to Dürrenmatt's Die Physiker - the Blackfoot maxim, "What was given to the great rocks can never be taken back", matches the end result of Dürrenmatt's play, as spoken by Möbius, that “Was einmal gedacht wurde, kann nicht mehr zurückgenommen werden” (Dürrenmatt 85).

But the connection of the Brecht and Horace texts with the Native American myths also performs another function: It suggests a reason why Leben des Galilei needed the classical literary allusion to Horace in the first place. As noted above, the eating and the farting are related and opposite attributes, and the mythology only manages to unite the two attributes in their protagonist by exploiting the freedom of giving the same character different attributes in different versions of the myth. A literary text, whether Brecht or Horace, has only one version. This means it would normally be restricted to giving its protagonist only one of the two opposite attributes. But one technique that can still create room for both of the attributes is to include a second text within the main text, giving the protagonist of the main text one attribute, and giving the protagonist of the second, included text the opposite attribute. This is precisely what happens in Leben des Galilei-in the main text, Galileo is associated with eating, but he is also equated with 
Priapus of Satire 1.8, and Priapus is associated with farting, thus creating a full parallel to the myth cycle, complete with opposite attributes, which would normally be impossible in a literary text with a unique version. This, then, could be an answer to the question, raised at the end of the previous section, about the purpose of Brecht's painstaking foregrounding of his Horatian intertext.

Of course, the myth cycle does not really unite the opposite attributes, but rather uses the opposite attributes, separated from each other, in two different versions of the myth. But precisely that convergence of opposites is the entire goal of mythology, according to the structure originally proposed by Lévi-Strauss, "the form through which a given mythic material seeks to transform a problematical starting point into a satisfactory solution" (Jameson, Prison-House of Language, 161).

And the same structural peculiarity of mythology — that it is, essentially, a machine that can "transform a problematic starting point to a satisfactory solution" (ibid.) - could be an answer to the question raised about the first section of the present chapter, the question about the means by which Brecht creates a sense of hope at the end of Leben des Galilei, or at least creates an open ending, where other playwrights, such as Dürrenmatt, Max Frisch, or Ionesco, could write nothing beyond absurdity, despair, darkness, hopelessness on the theme. The means Brecht brings to bear on the problem is the structure of mythology. The reason why he is successful is that, as Lévi-Strauss demonstrates, the structure of mythology is machine that is custom-built for the specific purpose of resolving impossible problems.

In conclusion, it is highly improbable that Brecht ever even heard of the cycle of Native American myths about the goatsucker. One must ask, then, why there should be 
structures characteristic of mythology in Brecht's play. This is the question addressed in the next chapter. 


\section{CHAPTER FOUR: WHY MYTHIC STRUCTURE IN LEBEN DES GALILEI?}

The mythic side of Leben des Galilei has an interesting contrast in certain writings of Antonin Artaud (1896-1948). Artaud was deeply impressed by a Balinese performance, which was mythic in nature (Artaud 53-67); yet when he wrote manifestos for theatre - he wrote two manifestos (Artaud 89-100, 122-132) — he did not make use of the deep structure of myths. Brecht, on the other hand, does have mythic structure in Leben des Galilei, as seen in the previous chapter; yet his theoretical writings do not so much as mention myth.

It is not as though the mythic did not receive explicit mention in Brecht because Brecht did not spend time on theory. He did, but the thrust of his theoretical writings is different: He spent his career developing the theory and methods of epic theatre. A brief summary of epic theatre is given below for easy reference.

Elements of epic theatre appeared in Brecht's work at least as early as the one-act play Die Kleinbürgerhochzeit (1919, but not premiered until 1926; Brecht, Die Stücke von Bertolt Brecht in einem Band, 907-920), of which a commentator remarks, "Das Stuick ist kalt zu spielen. Es erfordert eine innerliche Nichtbeteiligung des Schauspielers, der seine ganze Aufmerksamkeit auf das zu richten hat, was er macht. Es ist in der Tat voller Epik, voller Verfremdung, lange ehe diese Begriffe im Vokabular Brechts auftauchen" (Melchinger, "Das Theater des jungen Brecht," 62). The two differences between a tendency and a technique are: first, an author is conscious about his or her techniques, but not necessarily conscious about his or her tendencies; second, an author follows his or her techniques with intention, but might follow his or her tendencies unintentionally. Brecht's tendency of the "innerliche Nichtbeteiligung des 
Schauspielers" (ibid.) developed, fairly rapidly, into a technique. By the time Brecht applied it to Aufstieg und Fall der Stadt Mahagonny (1930; Brecht, Die Stücke von Bertolt Brecht in einem Band, 203-226), he was sufficiently sure of his new technique that he announced it in a theoretical note about the opera - this, then, marks the point where the new technique ceased to be experimental and solidified into a final form, into a theory. Brecht named his technique epic theatre, and defined it by outlining the ways in which it differed from the prevalent theatre. He listed the differences, as a scientist might do, in tabular form. The table, in full, is this:

Table 1: Epic Theatre, As Distinct from Dramatic Theatre, According to Brecht

\begin{tabular}{|l|l|}
\hline Dramatische Form des Theaters & Epische Form des Theaters \\
\hline \hline Die Bühne "verkörpert" einen Vorgang & sie erzählt ihn \\
\hline verwickelt den Zuschauer in eine Aktion und & macht ihm zum Betrachter, aber \\
\hline verbraucht seine Aktivität & weckt seine Aktivität \\
\hline ermöglicht ihm Gefühle & erzwingt von ihm Entscheidungen \\
\hline vermittelt ihm Erlebnisse & vermittelt ihm Kenntnisse \\
\hline $\begin{array}{l}\text { der Zuschauer wird in eine Handlung } \\
\text { hineinversetzt }\end{array}$ & er wird ihn gegenübergesetzt \\
\hline es wird mit Suggestion gearbeitet & es wird mit Argumenten gearbeitet \\
\hline die Empfindungen warden konserviert & bis zu Erkenntnissen getrieben \\
\hline der Mensch wird als bekannt vorausgesetzt & $\begin{array}{l}\text { der Mensch ist Gegenstand der } \\
\text { Untersuchung }\end{array}$ \\
\hline der unveränderliche Mensch & der veränderliche und verändernde Mensch \\
\hline Spannung auf den Ausgang & Spannung auf den Gang \\
\hline eine Szene für die andere & jede Szene für sich \\
\hline die Geschehnisse verlaufen linear & in Kurven \\
\hline natura non facit saltus & facit saltus \\
\hline die Welt, wie sie ist & die Welt, wie sie wird \\
\hline was der Mensch soll & was der Mensch muß \\
\hline seine Triebe & seine Beweggründe \\
\hline das Denken bestimmt das Sein & $\begin{array}{l}\text { das gesellschaftliche Sein bestimmt das } \\
\text { Denken }\end{array}$ \\
\hline
\end{tabular}

(Brecht, Schriften zum Theater, 116-117; see also Szondi 116-117, Bentley 43-44)

It is possible to visually represent epic theatre as a triangle - let us call it $\triangle A B C$ - with the audience at vertex $A$, the Brechtian actor at vertex $B$, and the character the actor is 
playing at vertex $C$. In other words, the audience, the actor, and the character remain at some distance from one another, separated, as though they were, by the three side lengths of the triangle they form. The actor does not become his or her character, and members of the audience do not identify with either the actor or the character. The play consists of the actor, firmly planted at vertex $B$, pointing out the character fixed at vertex $C$ to the viewer, effectively saying, "Look, over there is the character!" The viewer watches everything — both the actor and, as a completely separate entity, the character-from the safe distance of vertex $A$. The creation of the three distances between the triangle's three vertices is Brecht's famous Verfremdungseffekt. The distance between the viewer and the character enables the viewer to genuinely see the character, rather than merely gawking at the character, and then the effect is even further magnified if the viewer happens to recognize a reflected image of himself or herself in the character (Haus, "Gedanken vor einer Inszenierung des Leben des Galilei 1988 in den USA,” 22).

Perhaps because he intended Leben des Galilei to be his final statement, Brecht even integrated the distinction between seeing and gawking into its text, as a recent commentator points out: "In seinem Jahrzehnten später erstandenen Theatertext Leben des Galilei greift er das Sehen - jetzt akzentuiert als Erkenntnismittel - wieder auf und konfrontiert es erneut mit dem Begriff 'Glotzen,' also einem begrifflosen Blick der an der Oberfläche verbliebenden Anschauung” (Vaßen, “"Jeder sollte sich von sich selbst entfernen.' - Fremdheit und Verfremdung bei Bertolt Brecht,” 202; see also Torby 96). Finally, the status of the resulting seeing, as distinct from gawking, as "Erkenntnismittel" makes it possible for the theatre to function as a medium of education, i.e. makes possible the Brechtian Lehrstück. 
In the same note-about Aufstieg und Fall der Stadt Mahagonny, the note where he tabulated the differences between dramatic theatre and epic theatre-Brecht also addressed the question of what music suits epic theatre:

Table 2: The Music of Epic Theatre, As Distinct from the Music of Dramatic Theatre

\begin{tabular}{|l|l|}
\hline Dramatische Oper & Epische Oper \\
\hline \hline Die Musik serviert & Die Musik vermittelt \\
\hline Musik den Text steigernd & den Text auslegend \\
\hline Musik den Text behauptend & den Text voraussetzend \\
\hline Musik illustrierend & Stellung nehmend \\
\hline Musik die psychische Situation malend & das Verhalten gebend \\
\hline
\end{tabular}

(Brecht, Schriften zum Theater, 118-119; see also Bentley 44)

The tabulated differences, of course, only directly address the music that Kurt Weill (1900-1950) wrote for Aufstieg und Fall der Stadt Mahagonny. But the music for Leben des Galilei, written by Hanns Eisler (1898-1962), also matches both the guidelines set out in the last table and, generally, the epic theatre. An article about a recent production of the play with Eisler's original music mentions, among other things, "the quality of the songs as lessons" (Henderson 123), "a melodic line based on sol mi la, a quote of the childhood taunting tune, and an alienation effect" (Henderson 123), and "a repeated rising perfect fourth, reminiscent of another childhood taunt, and another example of the alienation effect" (Henderson 125). Thus the music is included as an essential part in the theory of epic theatre, and, in Leben des Galilei, it contributes to the Verfremdungseffekt and to the play's quality of being a Lehrstück. Of course, beyond the text and the music, other aspects of the production, such as costume and make-up, can also contribute to Verfremdungseffekt, and productions of Brecht's plays often take pains in those departments as well (see, for example, Barrier 128).

In Brecht's system, epic theatre produced Verfremdungseffekt as one of its defining consequences. One of the means by which Brecht's the system constructed epic 
theatre was the acting technique of Gestus. A Gestus is a well-chosen gesture the actor foregrounds in the portrayal of a character. The Gestus becomes representative, by means of metonymy, either of the character, or of the character's relationship to another character. The term is not Brecht's invention, but rather dates at least as far back as the $18^{\text {th }}$ century (see, for example, Lessing, paragraph 7), but Brecht re-invented it and developed it into an identification symbol of his epic theatre. In a celebrated example from Mutter Courage und ihre Kinder (1941; Brecht, Die Stücke von Bertolt Brecht in einem Band, 541-578), "when Mother Courage bites on the coin offered by the recruiting sergeant and, as a result of this brief interval of distrust, loses her son, she demonstrates at once her past as tradeswoman and the future that awaits her - all her children dead in consequence of her money-making blindness" (Barthes 73)—Gestus is a gesture that affects the entire course of events of a play. Brecht himself explained how Galileo's behavior toward Andrea in the opening scene of Leben des Galilei functions as Gestus to determine the outcome of the two characters' final meeting in the play's penultimate scene (Brecht, Brecht on Theatre, 198-200). More specifically—more specific because Gestus is not uniquely specified by a Brecht's relatively permissive texts, but rather created afresh by each actor-effective use of Gestus was crucial in multiple ways in the construction of Charles Laughton's Galileo for the play's American production (Maclean 80, 89; see also Brecht, Collected Plays, 253 for one way Laughton revised his Gestus between the Beverly Hills production and the New York production).

Brecht's collaboration with Laughton, while important to both men's separate artistic developments, ended on a sour note with the New York production (see, for example, Neilson 290 et seq.). Brecht wrote a poetic denunciation of Laughton in the 
form of an epitaph, even though he would himself pre-deceased Laughton by six and a half years:

Speak of the weather

Be thankful he's dead

Who before he had spoken

Took back what he said. (Neilson 296)

Thus, even the means Brecht uses to condemn Laughton in the epitaph is a Gestus- the gesture of failing to be true to one's word.

And the practice of Gestus, indeed its importance, did not die with Brecht's death. Gestus, being relatively transcultural by nature - more transcultural, for example, than music, which Brecht discusses in the table quoted above- has also proved crucial to successful contemporary productions of Brecht in new cultural contexts beyond the ones originally visualized by Brecht, such as in Brazilian Portuguese (Heeg 267 et seq.). Separately, work with Gestus continued in the Berliner Ensemble (Maclean 90) and in the work of Heiner Müller (1929-1995) (Maclean 93 et seq., Mumford 46). Of particular interest, in view of the substance of this thesis, is Heiner Müller's development of Gestus in the specific direction of intertextuality: "What Müller substitutes in place of a linear sequence is history, not history as story, but history as intertextuality or as quotation, what Müller calls 'Zitatgestus' or 'Gestus of quotation'” (Maclean 93)_Müller took the Brecht's intertextual tendency — as analyzed in chapter three above — and turned it, by practising it consciously and with intent, into his own technique of Zitatgestus. In particular, Zitatgestus is one example of a post-Brechtian technique that originated in later experiments with Brecht's technique of Gestus. 
The above are some of Brecht's own thoughts on theatre and some of the ways he practised it. As mentioned at the beginning of the present chapter, in Brecht's theory, the entire topic of myth is conspicuous by its absence. The question remains, then, why Leben des Galilei has the mythic structure demonstrated in the previous chapter.

And the answer may lie in the universal, primitive nature that has been hypothesized for mythic thought (see, for example, Jameson, Prison-House of Language, 111 et seq.; see also Lévi-Strauss 191), which makes it at least consistent that a text, if worked out to a state of completion, would ultimately feature mythic structure. That is, because Brecht worked on Leben des Galilei for twenty years, the play necessarily had to arrive at something that is universal in nature; the play has the mythic structure because mythic structure is the universal structure at which the play arrived - this is a possible answer to the question of the present chapter.

And, working in the opposite direction, one could try to draw conclusions using the existence of mythic structure in Leben des Galilei as the starting point. The Native American myth cycle and Brecht's play are two texts that developed independently of each other. After extensive reworking - after three versions spread out over two decades for Brecht, after oral retelling over generations in different Native American tribes for the myth cycle - the same structure appears in both texts. This might be evidence of the existence of archetypes of texts, and Leben des Galilei might belong to the same archetype as the goatsucker myth. 


\section{Works Cited}

Alder. Kurt, et al. "Mainauer Kundgebung." The Mainau Declaration 1955 on Nuclear Weapons, Lindau Nobel Laureate Meetings, 15 July 1955, https://irpcdn.multiscreensite.com/26063ee7/dms3rep/multi/mainau-declaration-19554050x3303.jpg. Accessed 11 June 2018.

Allen, Graham. Intertextuality. 2nd ed., Routledge, 2011.

Arendt, Hannah. "Der Dichter Bertolt Brecht." Die Neue Rundschau, vol. 61, 1950, pp. $53-67$.

---. "The Poet Bertolt Brecht." Brecht: A Collection of Critical Essays, edited by Peter Demetz, Prentice-Hall, 1962, pp. 43-50.

Artaud, Antonin. The Theater and its Double. Translated by Mary Caroline Richards, Grove Press, 1958.

Barrier, Andrea. "Designing Galileo." Communications from the International Brecht Society, vol. 36, Fall 2007, pp. 127-129.

Barthes, Roland. Image Music Text. Translated by Stephen Heath, Fontana Press-Harper Collins Publishers, 1977.

Benjamin, Walter. Versuche über Brecht. 5. Auflage, Suhrkamp Verlag, 1978.

Bentley, Eric. The Brecht Commentaries. Second Evergreen edition, Grove Press, 1987. Borchardt, Frank K. “Marx, Engels, and Brecht's Galileo.” Das Brecht-Jahrbuch, vol. 2, 1972, pp. 149-163.

Born, Max, et al. "Russell-Einstein Manifesto.” Pugwash Conferences on Science and World Affairs, 9 July 1955, https://pugwash.org/1955/07/09/statement-manifesto/. Accessed 11 June 2018. 
Borneman, Ernest. "Two Brechtians.” The Kenyon Review, vol. 22, no. 3, Summer 1960, pp. $465-492$.

Boroditsky, Lera, et al. "What is Universal in Event Perception? Comparing English \& Indonesian Speakers.” Proceedings of the Twenty-Fourth Annual Conference of the Cognitive Science Society, edited by Wayne D. Gray and Christian Schunn, Psychology Press, 2002, pp. 136-141.

Brecht, Bertolt. Brecht on Theatre. Edited and translated by John Willett, Hill and Wang, 1964.

---. Collected Plays. Edited by Ralph Manheim and John Willett, Associate

Editor Wolfgang Sauerlander, vol. 5, Vintage Books-Random House, 1972.

---. "Darstellung der Kirche.” Materialien zu Brechts >Leben des Galilei<, edited by Werner Hecht, Suhrkamp Verlag, 1976, pp. 14-15.

---. "Das sinnliche in Galilei." Materialien zu Brechts `Leben des Galilei<, edited by Werner Hecht, Suhrkamp Verlag, 1976, p. 28.

---. "Der neue Physikertyp.” Materialien zu Brechts `Leben des Galilei<, edited by Werner Hecht, Suhrkamp Verlag, 1976, p. 27.

---. Die Stücke von Bertolt Brecht in einem Band. Suhrkamp Verlag, 1978.

---. Geschichten von Herrn Keuner. Suhrkamp Verlag, 1971.

---. Kalendergeschichten. W. W. Norton, 1960.

---. “»Leben des Galilei« ist keine Trägodie.” Materialien zu Brechts `Leben des Galilei<, edited by Werner Hecht, Suhrkamp Verlag, 1976, p. 13.

---. "Portrayal of the Church." Collected Plays, edited by Ralph Manheim and John Willett, Associate Editor Wolfgang Sauerlander, vol. 5, Vintage Books-Random 
House, 1972, pp. 216-217.

---. “Praise or Condemnation of Galileo?" Collected Plays, edited by Ralph Manheim and John Willett, Associate Editor Wolfgang Sauerlander, vol. 5, Vintage BooksRandom House, 1972, pp. 224-225.

---. "Preis oder Verdammung des Galilei?" Materialien zu Brechts `Leben des Galilei`, edited by Werner Hecht, Suhrkamp Verlag, 1976, pp. 12-13.

---. Schriften zum Theater, vol. 2. Suhrkamp Verlag, 1963.

---. "The Life of Galileo Is Not a Tragedy." Collected Plays, edited by Ralph Manheim and John Willett, Associate Editor Wolfgang Sauerlander, vol. 5, Vintage BooksRandom House, 1972, p. 216.

---. "The New Type of Physicist." Collected Plays, edited by Ralph Manheim and John Willett, Associate Editor Wolfgang Sauerlander, vol. 5, Vintage Books-Random House, 1972, p. 218.

---. "The Sensual Element in Galileo." Collected Plays, edited by Ralph Manheim and John Willett, Associate Editor Wolfgang Sauerlander, vol. 5, Vintage BooksRandom House, 1972, pp. 218-219.

Browning, William. "Defining Dialectics between Space and Storytelling." Communications from the International Brecht Society, vol. 36, Fall 2007, pp. $112-115$.

Caldwell, Ellen C. "Poststructuring Brecht: Pluralism and Propaganda in Galileo." Communications from the International Brecht Society, vol. 17, no. 2, April 1988, pp. $38-47$.

Chambers, Ross. Story and Situation: Narrative Seduction and the Power of Fiction. 
University of Minnesota Press, 1984.

Danter, Matej. "History of Changes of Brecht's Galileo." Bertolt Brecht's Galileo, New Mexico State University,12 Dec. 2006, https://web.archive.org/web/ 20061214065712/http://www.nmsu.edu:80/ honors/galileo/gchanges.html. Accessed 1 June 2018.

Davison, Richard A. "Notes on Heinz-Uwe Haus Rehearsing Brecht's Galileo.” Communications from the International Brecht Society, vol. 36, Fall 2007, pp. $108-111$.

Demetz, Peter, editor. Brecht: A Collection of Critical Essays. Prentice-Hall, 1962.

Dürrenmatt, Friedrich. Die Physiker: Komödie. Diogenes Verlag, 2001.

Empson, William. Seven Types of Ambiguity. $2^{\text {nd }}$ ed. (revised and re-set), 1947. New Directions, 1949.

Esslin, Martin. Brecht: A Choice of Evils. 1959. Eyre \& Spottiswoode, 1963.

Frenzel, Herbert A. and Elisabeth Frenzel. Daten deutscher Dichtung, vol. 2, 1962. Deutscher Taschenbuch Verlag, 2007.

Frisch, Max. Biedermann und die Brandstifter: ein Lehrstück ohne Lehre, mit einem Nachspiel. Suhrkamp Verlag, 1958; edited by Paul Kurt Ackermann, Houghton Mifflin, 1963.

---. “Brecht der Priester.” Die Zeit, Nr. 42, 19. Oktober 1950, Aktualisiert am 21. November 2012, www.zeit.de/1950/42/brecht-der-priester. Accessed 28 Jan. 2018.

---. "Recollections of Brecht." Translated by Carl R. Mueller, The Tulane Drama Review, vol. 6, no. 1, Sep. 1961, pp. 33-38. 
---. Tagebuch 1946-1949. Suhrkamp Verlag, 1970.

Grimm, Reinhold. Bertolt Brecht: Die Struktur seines Werkes. 5., durchgesehene und ergänzte Auflage, Verlag Hans Carl Nürnberg, 1968.

---. "Der Nolaner und der Pisaner: Zwei Italiener bei Bertolt Brecht und Volker Braun." Das Brecht-Jahrbuch, vol. 28, 2003, pp. 172-187.

Harman, Mark. "Brecht in Motion: Translating Galileo to the American Stage." Communications from the International Brecht Society, vol. 36, Fall 2007, pp. $116-121$.

Haus, Heinz-Uwe. “Gedanken vor einer Inszenierung des Leben des Galilei 1988 in den USA.” Communications from the International Brecht Society, vol. 17, no. 1, Nov. 1987, pp. 21-23.

---. "What Can a Galileo Production Reveal?" Communications from the International Brecht Society, vol. 36, Fall 2007, pp. 130-132.

Hecht, Werner, editor. Materialien zu Brechts `Leben des Galilei.` Suhrkamp Verlag, 1976.

Heeg, Günther. “Das transkulturelle Potential der Geste. Zur Aktualität von Brechts Konzept eines gestischen Theaters.” Das Brecht-Jahrbuch, vol. 38, 2013, pp. $260-271$.

Henderson, Linda. "Music of the Spheres: Singing Actors in The Life of Galileo." Communications from the International Brecht Society, vol. 36, Fall 2007, pp. $121-126$.

Horace. The Works of Horace. Translated by C. Smart, vol. 2, T. Carnan, 1780. von Humboldt, Wilhelm. "Ueber das vergleichende Sprachstudium in Beziehung auf die 
vershiedenen Epochen der Sprachentwicklung." Wilhelm von Humboldts Werke, Bd. 4, edited by Albert Leitzmann, B. Behr's Verlag, 1905, pp. 1-34.

Ionesco, Eugène. Notes \& Counter Notes: Writings on the Theatre. Translated by Donald Watson, Grove Press, 1964.

Jameson, Fredric. Brecht and Method. Verso, 1999.

---. The Prison-House of Language. Princeton University Press, 1972.

Knust, Herbert. "Book Reviews: Werner Zimmermann. Bertolt Brecht: Leben des Galilei. Dramatik der Widersprüche. Paderborn, Munich, Vienna, Zürich: Schöningh, 1985. 142 pages.” Das Brecht-Jahrbuch, vol. XIV, 1989, pp. 186187.

Kruger, Loren. "Theater Translation as Reception: the Example of Brecht's Galileo." Communications from the International Brecht Society, vol. XIV, no. 2, April 1985, pp. 34-47.

Lessing, Gotthold Ephraim. "Viertes Stück.” Hamburgische Dramaturgie, 12 May 1767, http://gutenberg.spiegel.de/buch/hamburgische-dramaturgie-1183/6. Accessed 24 June 2018.

Lévi-Strauss, Claude. The Jealous Potter. Translated by Bénédicte Chorier, The University of Chicago Press, 1988.

Maclean, Hector. "Gestus in Performance: Brecht and Heiner Müller.” Das Brecht-Jahrbuch, vol. 26, 2001, pp. 80-99.

Maslow, A. H. “A Theory of Human Motivation.” Psychological Review, vol. 50, no. 4, 1943, pp. 370-396.

---. Motivation and Personality. Harper and Row, 1987. 
Melchinger, Siegfried. "Das Theater des jungen Brecht." Theater heute, vol. 4, no. 12, 1963, pp. 61-62.

---. "Mahagonny als Mysterienspiel.” Theater heute, vol. 5, no. 5, 1964, pp. 32-35.

Mumford, Meg. "Barthes on Brecht's Tableau: Fetish Meets Flux.” Communications from the International Brecht Society, vol. 32, 2003, pp. 42-47.

Neilson, George. 'From 'Building up a Part: Laughton's Galileo' to 'Epitaph for Ch.L.': Birth and Death of the Brecht/Laughton Collaboration.” Das Brecht-Jahrbuch, vol. 32, 2007, pp. 280-299.

Ohlson, Monica. “Galilei in Schweden.” Das Brecht-Jahrbuch, vol. 5, 1975, pp. 164167.

Propp, Vladimir Iakovlevich. Morphology of the Folktale. Translated by Laurence Scott, University of Texas Press, 1968.

Rohrmoser, Günther. "Brecht · Das Leben des Galilei.” Das deutsche Drama, edited by Benno von Wiese, vol. 2, August Bagel Verlag, 1962, pp. 401-414.

---. "Brecht's Galileo.” Brecht: A Collection of Critical Essays, edited by Peter Demetz, Prentice-Hall, 1962, pp. 117-126.

Schumacher, Ernst. Drama und Geschichte: Bertolt Brechts >Leben des Galilei< und andere Stücke. Henschel Verlag, 1965.

---. "Wie Brecht beinahe ein Einstein-Stück schrieb.” Der Freitag, 15 April 2005, https://www.freitag.de/autoren/der-freitag/wie-brecht-beinahe-ein-einstein-stuckschrieb. Accessed 1 June 2018.

Sharland, Suzanne. "Priapus' Magic Marker: Literary Aspects of Horace, 'Satire' 1.8." Acta Classica, vol. XLVI, 2003, pp. 97-109. 
Simpson, Patricia Anne. "Revolutionary Reading: the Circulation of Truth in Brecht's Leben des Galilei." Das Brecht-Jahrbuch, vol. 15, 1990, pp. 165-185.

Spencer, Andy. "Life of Galileo." Communications from the International Brecht Society, vol. 35, Fall 2006, pp. 51-54.

Squiers, Anthony. "A Short Organum on Ideology: Brecht on the Bourgeois Weltanschauung." Communications from the International Brecht Society, vol. 42, 2013, pp. 44-45.

---. "Visibility, Divisibility and the Language of Revolution: a Brechtian Perspective." Communications from the International Brecht Society, vol. 41, 2012, pp. 39-41.

Stegmann, Vera Sonja. "Casebook: The Life of Galileo." Communications from the International Brecht Society, vol. 36, Fall 2007, pp. 132-135.

Stern, Guy. "The Plight of the Exile: a Hidden Theme in Brecht's >Galileo Galilei.»" Das Brecht-Jahrbuch, vol. 1, 1971, pp. 110-116.

Suvin, Darko. "Brecht's Parable of Heavenly Food: Life of Galileo." Das BrechtJahrbuch, vol. 15, 1990, pp. 186-214.

Szondi, Peter. Theorie des modernen Dramas. 1959. Suhrkamp Verlag, 1964.

Todorov, Tzvetan. The Fantastic: A Structural Approach to a Literary Genre. Translated by Richard Howard, with a new foreword by Robert Scholes, Cornell University Press, 1975.

---. The Poetics of Prose. Translated by Richard Howard, with a new foreword by Jonathan Culler, Cornell University Press, 1977.

Torby, A.Q. “Casebook: The Life of Galileo." Communications from the International Brecht Society, vol. 36, Fall 2007, pp. 96-99. 
Tynan, Kenneth, et al. "Brecht und Ionesco - Pole des modernen Welttheaters." Theater heute, vol. 1, no. 2, 1960, pp. 23-28.

Unwin, Stephen. A Guide to the Plays of Bertolt Brecht. Methuen Publishing LimitedBloomsbury Publishing Plc, 2005.

Vaßen, Florian. “'Jeder sollte sich von sich selbst entfernen.' - Fremdheit und Verfremdung bei Bertolt Brecht.” Das Brecht-Jahrbuch, vol. 37, 2012, pp. 189 213.

---. “Die Alterität des Zuschauers. Das Theater braucht Widerstand - Bertolt Brechts Kritik am “Eintheatern.”” Das Brecht-Jahrbuch, vol. 39, 2014, pp. 74-88. de la Viña, Mark. "Galileo at the Berkeley Rep." Communications from the International Brecht Society, vol. 29, nos. 1 \& 2, June 2000, pp. 40-41. Weisstein, Ulrich. "Brecht in America: A Preliminary Survey." $M L N$, vol. 78, no. 4, German Issue, Oct. 1963, pp. 373-396.

von Wiese, Benno, editor. Das deutsche Drama, vol. 2. August Bagel Verlag, 1962. Willett, John. Brecht in Context. 1984. Methuen, 1986.

---. The Theatre of Bertolt Brecht. Methuen, 1959; revised in 1967 and 1977.

Zimmermann, Werner. Bertolt Brecht: Leben des Galilei. Dramatik der Widersprüche. Schöningh, 1985.

Zipser, Richard A. "Brecht and Galileo in Delaware." Communications from the International Brecht Society, vol. 36, Fall 2007, pp. 99-102.

Zuther, Gunther. "Brecht Seminar at MLA.” Modern Drama, vol. 11, no. 4, Winter 1968, p. 422. 
Appendix: Horace's Satire 1.8

Q. Horatii Flacci

Satyrarum

Liber I.

Satyra VIII.

Conqueritur Priapus Esquilinum montem veneficarum incantationibus infestari.

Olim truncus eram ficulnus, inutile lignum :

Cum faber incertus scamnum faceretne Priapum,

Maluit esse Deum. Deus inde ego, furum aviumque

Maxima formido ; nam fures dextra coercet,

5 Obscœnoque ruber porrectus ab inguine palus :

Ast inportunas volucres in vertice harundo

Terret fixa, vetatque novis considere in hortis.

Huc prius angustis eiecta cadavera cellis

Conservus vili portanda locabat in arca.

10 Hoc miseræ plebi stabat commune sepulcrum,

Pantolabo scurræ, Nomentanoque nepoti.

Mille pedes in fronte, trecentos cippus in agrum

Hic dabat ; heredes monumentum ne sequeretur.

Nunc licet Esquiliis habitare salubribus, atque

15 Aggere in aprico spatiari ; quo modo tristes

Albis informem spectabant ossibus agrum :

Cum mihi non tantum furesque, feræque suetæ

Hunc vexare locum, curæ sunt atque labori,

Quantum carminibus quæ versant atque venenis

20 Humanos animos. has nullo perdere possum

Nec prohibere modo, simul ac vaga luna decorum

Protulit os, quin ossa legant, herbasque nocentis.

Vidi egomet nigra succinctam vadere palla

Canidiam, pedibus nudis, passoque capillo,

25 Cum Sagana maiore ululantem. pallor utrasque

Fecerat horrendas adspectu. scalpere terram

Unguibus, et pullam divellere mordicus agnam

Cœperunt. cruor in fossam confusus, ut inde

Manis elicerent, animas responsa daturas.

30 Lanea et effigies erat altera cerea : maior

Lanea, quæ pœnis conpesceret inferiorem.

Cerea suppliciter stabat, servilibus, ut que

Iam peritura, modis. Hecaten vocat altera, sævam 
Altera Tisiphonen. Serpents, atque videres

35 Infernas errare canes ; lunamque rubentem, $\mathrm{Ne}$ foret his testis, post magna latere sepulcra.

Mentior at siquid, merdis caput inquiner albis

Corvorum ; atque in me veniat mictum atque cacatum

Iulius, et fragilis Pediatia, furque Voranus.

40 Singula quid memorem ? quo pacto alterna loquentes

Umbræ cum Sagana resonarint triste et acutum?

Utque lupi barbam variæ cum dente colubræ

Abdiderint furtim terries, et imagine cerea

Largior arserit ignis ? et ut non testis inultus

$45 \quad$ Horruerim voces Furiarum et facta duarum ?

Nam, displosa sonat quantum vesica, pepedi

Diffissa nate ficus, at illæ currere in urbem ;

Canidiæ dentis, altum Saganæ caliendrum

Excidere, atque herbas, atque incantata lacertis

50 Vincula, cum magno risuque iocoque videres.

From pages 68 and 70 of Horace's The Works of Horace, translated by C. Smart, vol. 2, T. Carnan, 1780. 